\title{
Towards a tracer-based conceptualization of meltwater dynamics and streamflow response in a glacierized catchment
}

\author{
Daniele Penna ${ }^{1}$, Michael Engel ${ }^{2}$, Giacomo Bertoldi ${ }^{3}$, and Francesco Comiti ${ }^{2}$ \\ ${ }^{1}$ Department of Agricultural, Food and Forestry Systems, University of Florence, via San Bonaventura 13, \\ 50145 Florence, Italy \\ ${ }^{2}$ Faculty of Science and Technology, Free University of Bozen-Bolzano, Piazza dell' Università 5, \\ 39100 Bolzano, Italy \\ ${ }^{3}$ Institute for Alpine Environment, EURAC - European Academy of Bolzano/Bozen, viale Druso 1, 39100 Bolzano, Italy \\ Correspondence to: Daniele Penna (daniele.penna@unifi.it)
}

Received: 1 July 2016 - Published in Hydrol. Earth Syst. Sci. Discuss.: 7 July 2016

Revised: 18 November 2016 - Accepted: 21 November 2016 - Published: 2 January 2017

\begin{abstract}
Multiple water sources and the physiographic heterogeneity of glacierized catchments hamper a complete conceptualization of runoff response to meltwater dynamics. In this study, we used environmental tracers (stable isotopes of water and electrical conductivity) to obtain new insight into the hydrology of glacierized catchments, using the Saldur River catchment, Italian Alps, as a pilot site. We analysed the controls on the spatial and temporal patterns of the tracer signature in the main stream, its selected tributaries, shallow groundwater, snowmelt and glacier melt over a 3year period. We found that stream water electrical conductivity and isotopic composition showed consistent patterns in snowmelt-dominated periods, whereas the streamflow contribution of glacier melt altered the correlations between the two tracers. By applying two- and three-component mixing models, we quantified the seasonally variable proportion of groundwater, snowmelt and glacier melt at different locations along the stream. We provided four model scenarios based on different tracer signatures of the end-members; the highest contributions of snowmelt to streamflow occurred in late spring-early summer and ranged between 70 and $79 \%$, according to different scenarios, whereas the largest inputs by glacier melt were observed in mid-summer, and ranged between 57 and $69 \%$. In addition to the identification of the main sources of uncertainty, we demonstrated how a careful sampling design is critical in order to avoid underestimation of the meltwater component in streamflow. The results of this study supported the development of a conceptual model of streamflow response to meltwater dynamics in the Saldur
\end{abstract}

catchment, which is likely valid for other glacierized catchments worldwide.

\section{Introduction}

Glacierized catchments are highly dynamic systems characterized by large complexity and heterogeneity due to the interplay of several geomorphic, ecological, climatic and hydrological processes. Particularly, the hydrology of glacierized catchments significantly impacts downstream settlements, ecosystems and larger catchments that are directly dependent on water deriving from snowmelt, glacier melt or high-elevation springs (Finger et al., 2013; Engelhardt et al., 2014). Water seasonally melting from snowpack and glacier bodies can constitute a larger contribution to annual streamflow than rain (Cable et al., 2011; Jost et al., 2012), and is widely used, especially in Alpine valleys, for irrigation and hydropower production (Schaefli et al., 2007; Beniston, 2012). It is therefore pivotal for an effective adoption of water resources strategies to understand the origin of water and to quantify the proportion of snowmelt and glacier melt in streamflow (Finger et al., 2013; Fan et al., 2015). To achieve this goal it is critical to gain a more detailed understanding of the hydrological functioning of glacierized catchments through the analysis of the spatial and temporal variability of water sources and the spatial and seasonal meltwater (snowmelt plus glacier melt) dynamics. 
Hydrochemical tracers (e.g. temporary storage of winterearly spring precipitation in the snowpack and in the glacier body and their melting during the late spring and summer controls the variability in solute and isotopic compositions of stream water (Kendall and McDonnell, 1998). Therefore, hydrochemical tracers allow for an effective identification of water sources and their variability within the catchments and over different seasons, providing essential information about water partitioning and water dynamics and improving our understanding of complex hydrology and hydroclimatology of the catchment (Rock and Mayer, 2007; Fan et al., 2015; Xing et al., 2015). Particularly, a few works relied on stable isotopes of water $\left({ }^{2} \mathrm{H}\right.$ and $\left.{ }^{18} \mathrm{O}\right)$ used in combination with $\mathrm{EC}$ to evaluate the role played by meltwater in the hydrology of glacierized catchments. For instance, some of these investigations allowed for the separation of streamflow into subglacial-, englacial-, melt- and rainfall-derived components in the South Cascade Glacier, USA (Vaughn and Fountain, 2005), into components due to monsoon rainfall runoff, post-monsoon interflow, winter snowmelt and groundwater (the latter estimated up to $40 \%$ during summer and monsoon periods) in the Ganga River, Himalaya (Maurya et al., 2011), and into snowmelt, ice melt and shallow groundwater components in Arctic catchments characterized by a gradient of glacierization (Blaen et al., 2014). Other researchers assessed the possibility to use isotopes and EC as complementary tracers, in addition to water temperature, to identify a permafrost-related component in spring water in a glacierized catchment in the Ortles-Cevedale massif, Italian Alps (Carturan et al., 2016).

Two recent studies used stable isotopes and EC over a 3year period to assess water origin and streamflow contributors in the glacierized Saldur River catchment, Italian Alps. Penna et al. (2014) showed a preliminary analysis on the highly complex EC and isotopic signature of different waters sampled in the catchment, identifying distinct tracer signals in snowmelt and glacier melt. These two end-members dominated the streamflow throughout the late spring and summer, whereas liquid precipitation played a secondary role, limited to rare intense rainfall events. They also assessed, without quantifying it, the switch from snowmelt- to glacier meltdominated periods, and estimated that the snowmelt fraction in groundwater ranged between 21 and $93 \%$. Engel et al. (2016) employed two- and three-component mixing models to quantify the relative contribution of snowmelt, glacier melt and groundwater to streamflow during seven representative melt-induced runoff events sampled at high frequency at two cross sections of the Saldur River. They observed marked reactions of tracers and streamflow both to melt and rainfall inputs, identifying hysteretic loops of contrasting directions. They estimated the maximum contribution of snowmelt during June and July events (up to $33 \%$ ) and of glacier melt during the August events (up to $65 \%$ ). However, a quantification of the variations of streamflow components not only at the seasonal scale but also at different spatial scales across the catchment was not performed and a conceptual model of meltwater dynamics was not presented. Therefore, despite the number of studies that have conducted hydrological tracer-based investigations in high-elevation mountain catchments, there is still the need to gain a better comprehension of the factors determining the complex hydrochemical signature of stream water and groundwater in glacierized catchments.

This research builds on the existing database for the Saldur River and on the first results presented in Penna et al. (2014) and Engel et al. (2016) to improve the knowledge of the complex hydrology and the water source dynamics in glacierized catchments. Specifically, we aim to

- assess the controls on the spatial and temporal variability of the isotopic composition and EC in the main stream, tributaries and springs in the Saldur River catchment;

- quantify the proportion of snowmelt and glacier melt in streamflow at different stream locations and at different times of the year, as well as the related uncertainty;

- analyse the relation between the tracer signature and streamflow variability;

- derive a conceptual model of streamflow response to meltwater dynamics.

\section{Study area}

The research has been conducted in the upper portion of the Saldur River catchment, Vinschgau Valley, eastern Italian Alps (Fig. 1). The catchment size is $61.7 \mathrm{~km}^{2}$ and altitude ranges between $1632 \mathrm{~m}$ a.s.l. at the outlet $\left(46^{\circ} 42^{\prime} 42.37^{\prime \prime} \mathrm{N}\right.$, $10^{\circ} 38^{\prime} 51.41^{\prime \prime} \mathrm{E}$ ) and $3725 \mathrm{~m}$ a.s.l. A glacier lies in the upper part of the catchment, with an extent of $2.28 \mathrm{~km}^{2}$ in 2013 , i.e. approximately $4 \%$ of the total catchment area (Galos and Kaser, 2013). The glacier lost $21 \%$ of its area from 2005 to 2013 (Galos and Kaser, 2013). Several glacier-fed and non-glacier-fed lateral tributaries contribute to the Saldur River streamflow, and various springs, apparently connected or not connected to the main stream, can be found on the valley floor and at the toe of the hillslopes in the midupper part of the catchment. Rocks are metamorphic, mainly gneisses, mica-gneisses and schists. Land cover changes with elevation typically varying from Alpine forests (up to about $2200 \mathrm{~m}$ a.s.1.) to shrubs to Alpine grassland, bare soil and rocks above $2700 \mathrm{~m}$ a.s. 1 . The area is characterized by a continental climate with an average annual air temperature of $6.6^{\circ} \mathrm{C}$ and precipitation as low as $569 \mathrm{~mm} \mathrm{yr}^{-1}$ (at $1570 \mathrm{~m}$ a.s.1.), likely increasing up to $800-1000 \mathrm{~mm} \mathrm{yr}^{-1}$ in the upper parts of the catchment. At $3000 \mathrm{~m}$ a.s.1., the total precipitation can be estimated, using the approach of Mair et al. (2016), to be about $1500 \mathrm{~mm}, 80 \%$ of which falls as snow. The hydrological regime is typically nivo-glacial with 


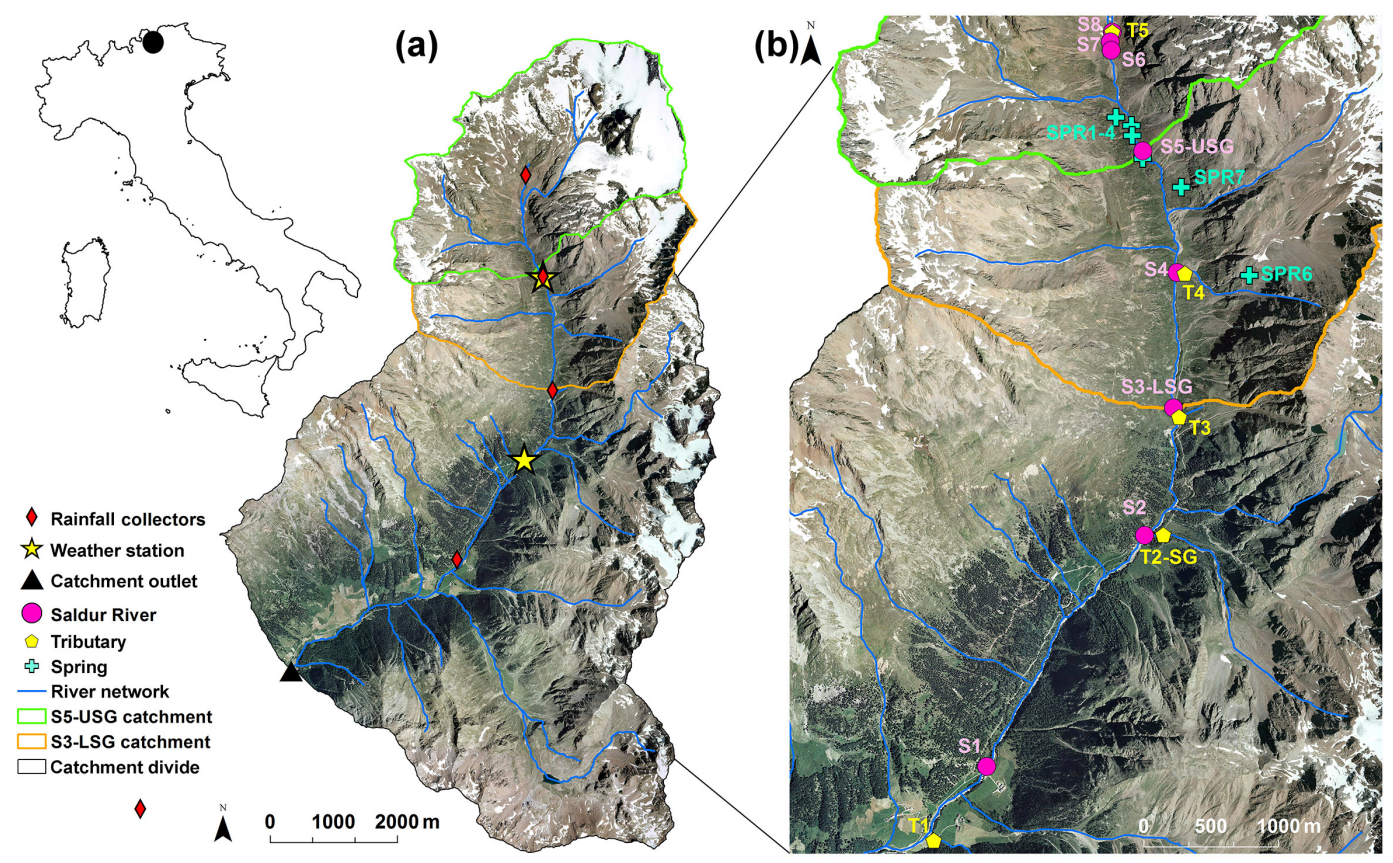

Figure 1. Map of the Saldur catchment, with its localization in the country, and position of field instruments and sampling points. Data from the rainfall collectors were not used in this study but their position is reported for completeness.

minimum streamflow recorded in winter and high flows occurring from late spring to mid-summer, when marked diurnal streamflow cycles occur, related to snowmelt and glacier melt (Mutzner et al., 2015). More detailed information on the study area are reported in Mao et al. (2014) and Penna et al. (2014).

\section{Materials and methods}

\subsection{Hydrological and meteorological measurements}

Field measurements were conducted from April 2011 to October 2013. Meteorological data were recorded at $15 \mathrm{~min}$ temporal resolution by two stations located at 2332 and 1998 m a.s.l. (Fig. 1a). The stage in the Saldur River was recorded every $10 \mathrm{~min}$ by pressure transducers at the catchment outlet and at two river sections labelled lower stream gauge (S3-LSG; $2150 \mathrm{~m}$ a.s.l.) and upper stream gauge (S5USG; $2340 \mathrm{~m}$ a.s.1.), which defined two nested subcatchments with an area of 18.6 and $11.2 \mathrm{~km}^{2}$, respectively (Fig. 1a). Streamflow values were obtained by 82 discharge measurements acquired by the salt dilution method during various hydrometric conditions over the three study years. Water level was also continuously measured on a left tributary (T2-SG; $2027 \mathrm{~m}$ a.s.l.; Fig. 1b) draining an area of $1.7 \mathrm{~km}^{2}$ but a robust rating curve was not available to derive streamflow.

\subsection{Tracer sampling and measurement}

Samples analysed for the two tracers were collected from snowmelt, glacier melt, stream water and groundwater. Snowmelt was sampled in late spring-early summer from water dripping from the residual snowpack at different elevations and different locations. Snowmelt was sampled on three occasions in summer 2012 (end of June, beginning and end of July), at elevations roughly between 2150 and $2350 \mathrm{ma}$ a.s.l., and on nine occasions in summer 2013 (June, July and August) at elevations roughly between 2150 and $2600 \mathrm{~m}$ a.s.l. Glacier melt was sampled from small rivulets flowing on the glacier surface, roughly at $2800 \mathrm{~m}$ a.s.l. in July and August 2012, and in July, August and September 2013. Grab stream-water samples were taken approximately monthly at eight locations in the Saldur River (labelled from S1 to S8), at elevations spanning from $1809 \mathrm{~m}$ a.s.1. (S1) and $2415 \mathrm{~m}$ a.s.l. (S8), and from five tributaries (labelled from T1 to T5), at elevations between $1775 \mathrm{~m}$ a.s.l. (T1) to $2415 \mathrm{~m}$ a.s.l. (T5; Fig. 1b). Samples at T1 were taken only in 2012, and samples at T3 only in 2011. In 2013 samples were collected monthly during clear days only from the river at four sections (S1, S3-LSG, S5-LSG, S8), respectively at the same time of the day on each occasion in order to ensure consistency and comparability between measurements. The representativeness of these samples for the typical melting conditions in the catchment was visually ensured by comparing the hydrographs of the sampled days with the ones of the corresponding months during the three monitored years. No wells are available in the study 
Table 1. Sampling years and number of samples collected from the different water sources and used in this study.

\begin{tabular}{llrr}
\hline Water source & $\begin{array}{l}\text { ID of sampling } \\
\text { locations }\end{array}$ & $\begin{array}{r}\text { Sampling } \\
\text { years }\end{array}$ & $\begin{array}{r}\text { Total no. } \\
\text { of samples }\end{array}$ \\
\hline Snowmelt & - & $2011-2013$ & 24 \\
\hline Glacier melt & - & $2012-2013$ & 16 \\
\hline \multirow{2}{*}{ Stream (main river) } & S1-S8 & $2011-2012$ & 535 \\
& S1, S3-LSG, S5-USG, S8 & 2013 & \\
\hline \multirow{2}{*}{ Stream (tributaries) } & T1 T2, T4, T5 & 2012 & \\
& T3 & $2011-2013$ & 102 \\
\hline \multirow{2}{*}{ Spring } & SPR1-SPR4 & $2011-2013$ & \\
& SPR6, SPR7 & 2013 & 84 \\
\hline
\end{tabular}

catchment; thus, spring water was assumed to represent shallow groundwater (Kong and Pang, 2012; Racoviteanu et al., 2013). Four springs (labelled from SPR1 to SPR4) localized near the outlet of USG, between 2334 and $2360 \mathrm{~m}$ a.s.l., were sampled monthly during the three study years. On one occasion (17 October 2011) no sample was taken from SPR1 because it was found dry. Additionally, monthly samples were also taken from June to September 2013 from two springs on the left valley hillslope, SPR6 and SPR7 at 2512 and $2336 \mathrm{~m}$ a.s.1., respectively (Fig. 1b). A list of all sampling locations with their main characteristics is reported in Penna et al. (2014).

In addition to the monthly sampling, stream water samples were collected at USG and LSG during seven runoff events induced by meltwater in July and August 2011, and June, July and August 2012 and 2013. Samples were collected from 10:00 LT of one day to 10:00 LT (or longer) on the following day at hourly frequency during the day until 22:00 LT, and every $3 \mathrm{~h}$ during the night. For those events, two- and three-component mixing models were applied to quantify the fraction of snowmelt and glacier melt in streamflow. Description of the runoff events and hydrograph separation results are reported in Engel et al. (2016). The number of samples collected from the different water sources at the various locations and years used in this study is reported in Table 1.

EC was determined directly in the field by means of a conductivity meter with a precision of $\pm 0.1 \mu \mathrm{S} \mathrm{cm}^{-1}$. The EC meter was routinely calibrated to ensure consistency among the measurements. Grab water samples for isotopic determination were taken by $50 \mathrm{~mL}$ HDPE (high-density polyethylene) bottles with two caps and completely filled to avoid head space. Isotopic analysis was carried out by an off-axis integrated cavity output spectroscope tested for precision, accuracy and memory effect in previous intercomparison studies (Penna et al., 2010, 2012). The observed instrumental precision, considered as the long-term average standard deviation, is $0.5 \%$ for $\delta^{2} \mathrm{H}$ and $0.08 \%$ ofor $\delta^{18} \mathrm{O}$. Isotopic values are presented using the $\delta$ notation referred to the SMOW2SLAP2 scale provided by the International Atomic Energy Agency.

\subsection{Two- and three-component mixing models and underlying assumptions}

A one-tracer, two-component mixing model (Pinder and Jones, 1969; Sklash and Farvolden, 1979) was used to quantify and separate two streamflow components (groundwater and snowmelt), and a two-tracer, three-component mixing model (Ogunkoya and Jenkins, 1993) was used for three streamflow components (groundwater, snowmelt and glacier melt). Mixing models were applied only to 2013 data because in that year water samples were collected at four locations along the main stream (S1, S3-LSG, S5-USG and S8) at the same time of the day on all sampling occasions. This was critical to ensure comparability of the results, given the high diurnal variability of streamflow and associated isotopic composition and EC, especially during the summer. In addition, results from the application of the two- and three-component mixing models to data collected hourly during seven melt-induced runoff events presented in Engel et al. (2016) were also used in this study for comparison purposes (see Sect. 4.3).

The following simplifying assumptions were made for the application of the mixing models:

- Streamflow at each selected sampling location of the Saldur River was a mixture of two components, viz. groundwater and snowmelt, or three components, viz. groundwater, snowmelt and glacier melt. The influence of precipitation was considered negligible because samples were collected during non-rainy periods, and particularly during warm, clear days when the meltwater input to runoff was remarkable and overwhelmed the possible presence of rain water in streamflow. 
- The largest contribution of snowmelt to streamflow was assumed to derive from snow melting at an approximate elevation of $2800 \mathrm{~m}$ a.s.l. The elevation band between 2800 and $2850 \mathrm{~m}$ a.s.l. was the one with the largest area in the catchment $\left(3.4 \mathrm{~km}^{2}\right)$, where much snow can accumulate, as confirmed by the analysis of snow cover data from Moderate Resolution Imaging Spectroradiometer (MODIS) images (cf. Engel et al., 2016).

The three-component mixing model was based on isotopic and EC data (Maurya et al., 2011; Penna et al., 2015) and first applied to all samples collected in the Saldur River in 2013. When the three-component mixing model yielded inconsistent results, typically in May and June and partially in October, it was inferred that there was no glacier melt component in streamflow; thus, the two-component mixing model was performed to separate the snowmelt from the groundwater component. As a preliminary step, both EC and isotopes were used in the two-component mixing model. The resulting estimates were strongly correlated $(p<0.01)$ but, overall, snowmelt fractions computed for May and June using isotopes were smaller compared to those computed through EC. In agreement with our previous work in the Saldur catchment (Engel et al., 2016), we decided to present EC-based results for the sampling days in May and June because of the large difference between the low EC of the snowmelt end-member and the relatively high EC of the stream that provided lower uncertainties in the estimated fractions compared to isotopes (Genereux, 1998). Conversely, for the sampling day in October, there was a relatively small difference between the EC of the groundwater end-member and the EC of the stream, while the difference in the isotopic signal of the end-members was greater, and thus the uncertainty in the estimated fractions was lower. Therefore, in these cases we used isotopes instead of EC in the two-component mixing model.

Based on the stated assumptions, the following mass balance equations can be written for periods when only snowmelt and groundwater contributed to streamflow:

$\mathrm{SF}=\mathrm{SM}+\mathrm{GW}$,

$1=\mathrm{sm}+\mathrm{gw}$,

$\delta_{\mathrm{SF}}=\mathrm{sm} \cdot \delta_{\mathrm{SM}}+\mathrm{gw} \cdot \delta_{\mathrm{GW}}$,

$\mathrm{EC}_{\mathrm{SF}}=\mathrm{sm} \cdot \mathrm{EC}_{\mathrm{SM}}+\mathrm{gw} \cdot \mathrm{EC}_{\mathrm{GW}}$,

where SM, GW and SF denote snowmelt, groundwater and streamflow, respectively; sm and gw indicate the streamflow fraction due to snowmelt and groundwater, respectively; and the notations $\delta$ and EC are used for the isotopic composition and the EC of each component, respectively. Equations (1)(4) can be solved for the unknown sm as follows:

$\operatorname{sm}(\%)=\frac{\delta_{\mathrm{SF}}-\delta_{\mathrm{GW}}}{\delta_{\mathrm{SM}}-\delta_{\mathrm{GW}}} \cdot 100$

or, using EC,
$\operatorname{sm}(\%)=\frac{\mathrm{EC}_{\mathrm{SF}}-\mathrm{EC}_{\mathrm{GW}}}{\mathrm{EC}_{\mathrm{SM}}-\mathrm{EC}_{\mathrm{GW}}} \cdot 100$.

The gw component can then be calculated by Eq. (2). Analogously, the following mass balance equations can be written for periods when snowmelt, glacier melt and groundwater contributed to streamflow:

$\mathrm{SF}=\mathrm{SM}+\mathrm{GM}+\mathrm{GW}$,

$1=\mathrm{sm}+\mathrm{gm}+\mathrm{gw}$,

$\delta_{\mathrm{SF}}=\mathrm{sm} \cdot \delta_{\mathrm{SM}}+\mathrm{gm} \cdot \delta_{\mathrm{GM}}+\mathrm{gw} \cdot \delta_{\mathrm{GW}}$,

$\mathrm{EC}_{\mathrm{SF}}=\mathrm{sm} \cdot \mathrm{EC}_{\mathrm{SM}}+\mathrm{gm} \cdot \mathrm{EC}_{\mathrm{GM}}+\mathrm{gw} \cdot \mathrm{EC}_{\mathrm{GW}}$,

where in additions to the symbols used in Eqs. (1)-(6), GM denotes glacier melt, and gm indicates the streamflow fraction due to glacier melt. Equations (7)-(10) can be solved for the unknown sm and gm as follows:

$$
\begin{aligned}
& \operatorname{sm}(\%)= \\
& \frac{\left(\delta_{\mathrm{SF}}-\delta_{\mathrm{GW}}\right) \cdot\left(\mathrm{EC}_{\mathrm{GM}}-\mathrm{EC}_{\mathrm{GW}}\right)-\left(\delta_{\mathrm{GM}}-\delta_{\mathrm{GW}}\right) \cdot\left(\mathrm{EC}_{\mathrm{SF}}-\mathrm{EC}_{\mathrm{GW}}\right)}{\left(\delta_{\mathrm{SM}}-\delta_{\mathrm{GW}}\right) \cdot\left(\mathrm{EC}_{\mathrm{GM}}-\mathrm{EC}_{\mathrm{GW}}\right)-\left(\delta_{\mathrm{GM}}-\delta_{\mathrm{GW}}\right) \cdot\left(\mathrm{EC}_{\mathrm{SM}}-\mathrm{EC}_{\mathrm{GW}}\right)} \cdot 100, \\
& \mathrm{gm}(\%)= \\
& \frac{\left(\delta_{\mathrm{SF}}-\delta_{\mathrm{GW}}\right) \cdot\left(\mathrm{EC}_{\mathrm{SM}}-\mathrm{EC}_{\mathrm{GW}}\right)-\left(\delta_{\mathrm{SM}}-\delta_{\mathrm{GW}}\right) \cdot\left(\mathrm{EC}_{\mathrm{SF}}-\mathrm{EC}_{\mathrm{GW}}\right)}{\left(\delta_{\mathrm{GM}}-\delta_{\mathrm{GW}}\right) \cdot\left(\mathrm{EC} \mathrm{SM}-\mathrm{EC}_{\mathrm{GW}}\right)-\left(\delta_{\mathrm{SM}}-\delta_{\mathrm{GW}}\right) \cdot\left(\mathrm{EC}_{\mathrm{GM}}-\mathrm{EC}_{\mathrm{GW}}\right)} \cdot 100 .
\end{aligned}
$$

The gw component can be then calculated by Eq. (8).

The uncertainty of the end-member fractions calculated through the two-component mixing model was quantified following the method of Genereux (1998) at the $70 \%$ confidence level. The uncertainty of the end-member fractions calculated through the three-component mixing model was determined by varying the isotopic composition and EC of each end-member by \pm 1 SD (standard deviation) (Carey and Quinton, 2005; Engel et al., 2016). All mixing models were applied using both $\delta^{2} \mathrm{H}$ and $\delta^{18} \mathrm{O}$ data; however, results based on $\delta^{18} \mathrm{O}$ measurements showed a greater uncertainty than those derived from $\delta^{2} \mathrm{H}$ data due to the instrumental performance (Penna et al., 2010). Thus, all results related to isotopes reported in this study are based on $\delta^{2} \mathrm{H}$ data.

\subsection{Scenarios of mixing model application}

The spatial and temporal variability of an end-member tracer signal is usually very difficult to characterize at the catchment scale (Hoeg et al., 2000), especially in glacierized catchments (Jeelani et al., 2016), and it can noticeably affect the uncertainty of the results of mixing models. Since field measurements cannot reliably capture such a large spatial and temporal variability, we identified four different scenarios of mixing model application, assuming that they were representative for this variability. The four scenarios differed considering the groundwater end-member based on springs or stream locations during baseflow conditions, and timeinvariant or monthly variable isotopic composition and EC 
Table 2. Summary of the properties of the end-members used in the four mixing model scenarios for 2013 data.

\begin{tabular}{llll}
\hline Scenario & Groundwater end-member & Snowmelt end-member & Glacier melt end-member \\
\hline A & $\begin{array}{l}\text { Average } \delta^{2} \mathrm{H} \text { and EC of samples } \\
\text { taken from selected springs in fall } \\
(2011-2013)\end{array}$ & $\begin{array}{l}\text { Time-invariant isotopic } \\
\text { composition and EC } \\
\text { (2013) }\end{array}$ & Monthly variable isotopic \\
B & $\begin{array}{l}\text { Average } \delta^{2} \mathrm{H} \text { and EC of samples } \\
\text { taken at each stream location in fall } \\
\text { and winter (2011-2013) }\end{array}$ & composition and EC (2013) \\
\hline C & $\begin{array}{l}\text { Average } \delta^{2} \mathrm{H} \text { and EC of samples } \\
\text { taken from selected springs in fall } \\
(2011-2013)\end{array}$ & $\begin{array}{l}\text { Monthly variable isotopic } \\
\text { composition and EC }\end{array}$ & \\
\hline & $\begin{array}{l}\text { Average } \delta^{2} \mathrm{H} \text { and EC of samples } \\
\text { taken at each stream location in fall } \\
\text { and winter }(2011-2013)\end{array}$ & & \\
D & & & \\
\hline
\end{tabular}

Table 3. Isotopic composition $\left(\delta^{2} \mathrm{H}\right)$ and EC of the groundwater end-member used in the two- and three-component mixing model for the four scenarios for 2013 data. $n$ : number of samples; avg.: average; SD: standard deviation.

\begin{tabular}{|c|c|c|c|c|c|c|c|c|c|c|c|c|}
\hline \multirow[b]{3}{*}{$\begin{array}{l}\text { Sampling } \\
\text { location }\end{array}$} & \multicolumn{6}{|c|}{$\delta^{2} \mathrm{H}(\% \circ)$} & \multicolumn{6}{|c|}{$\mathrm{EC}\left(\mu \mathrm{S} \mathrm{cm}^{-1}\right)$} \\
\hline & \multicolumn{3}{|c|}{ Scenarios A and C } & \multicolumn{3}{|c|}{ Scenarios B and D } & \multicolumn{3}{|c|}{ Scenarios $\mathrm{A}$ and $\mathrm{C}$} & \multicolumn{3}{|c|}{ Scenarios B and D } \\
\hline & $n$ & avg. & SD & $n$ & avg. & SD & $n$ & avg. & $\mathrm{SD}$ & $n$ & avg. & SD \\
\hline $\begin{array}{l}\text { S1 } \\
\text { S3-LSG }\end{array}$ & 7 & -101.7 & 5.7 & $\begin{array}{l}5 \\
3\end{array}$ & $\begin{array}{l}-101.5 \\
-101.7\end{array}$ & $\begin{array}{l}2.8 \\
1.4\end{array}$ & 7 & 317.7 & 76.6 & $\begin{array}{l}5 \\
3\end{array}$ & $\begin{array}{l}257.0 \\
298.0\end{array}$ & $\begin{array}{r}11.4 \\
6.6\end{array}$ \\
\hline $\begin{array}{l}\text { S5-USG } \\
\text { S8 }\end{array}$ & 5 & -98.5 & 1.3 & $\begin{array}{l}4 \\
1\end{array}$ & $\begin{array}{l}-101.6 \\
-101.8\end{array}$ & $\begin{array}{r}3.0 \\
(-) 0.5^{*}\end{array}$ & 5 & 288.2 & 40.7 & $\begin{array}{l}4 \\
1\end{array}$ & $\begin{array}{l}220.4 \\
210.0\end{array}$ & $\begin{array}{r}19.0 \\
(-) 0.1^{*}\end{array}$ \\
\hline
\end{tabular}

* For S8 only one sample was collected during baseflow conditions due to the difficult accessibility of the location in fall and winter; therefore, no standard deviation could be computed, and the instrumental precision was used for the computation of the uncertainty of the estimated fractions.

of the snowmelt end-member (Table 2). Particularly, in scenarios $\mathrm{A}$ and $\mathrm{C}$, the groundwater end-member was based on the average isotopic composition and EC of samples taken from springs during baseflow conditions in fall of the three study years (springs were not sampled during winter due to limited accessibility of the area), which is consistent with Engel et al. (2016) (Table 3). This assumes a negligible influence of the inter-annual variability of the climatic forcing on the tracer signal of spring water during baseflow. In scenarios B and D, the groundwater end-member was defined as the average of the tracer signal of different stream samples taken during baseflow conditions (late fall and winter of the three study years), at the four Saldur River locations selected in 2013 (Table 3). For the definition of these two groundwater end-members, we selected the samples taken during baseflow conditions when we assumed that there was no or negligible contribution of snowmelt, glacier melt and rainfall to streamflow. It is important to note that we consider as groundwater components both the spring baseflow and the stream baseflow, because the hydrochemistry of streams during baseflow conditions generally integrates and reflects the hydrochemistry of the (shallow) groundwater at the catchment scale (Sklash, 1990; Klaus and McDonnell, 2013; Fischer et al., 2015).

In scenarios $\mathrm{A}$ and $\mathrm{B}$, the tracer signature of the snowmelt end-member was considered time invariant (Maurya et al., 2011) (Table 4). Following Engel et al. (2016), the highelevation (2800 m a.s.l.) snowmelt isotopic composition was identified through the regression analysis of snowmelt samples collected at different elevations in June 2013, according to Eq. (13) $\left(R^{2}=0.616, n=7, p<0.05\right)$ :

$\delta^{2} \mathrm{H}(\% \circ)=-0.0705 \cdot$ elevation $(\mathrm{m}$ a.s.1. $)+37.261$.

$\mathrm{EC}_{\mathrm{SM}}$ was based on the average EC of all snowmelt samples collected in 2013, without applying any regression-based modification.

In scenarios $\mathrm{C}$ and $\mathrm{D}$, the isotopic composition of a highelevation snowmelt end-member was considered seasonally variable, taking into account that water from the melting snowpack typically undergoes progressive fractionation and isotopic enrichment over the season (Taylor et al., 2001; Lee et al., 2010) (cf. Sect. 4.1). A depletion rate of $-7.0 \%$ in $\delta^{2} \mathrm{H}$ 
Table 4. Isotopic composition $\left(\delta^{2} \mathrm{H}\right)$ and EC of the snowmelt end-member used in the two- and three-component mixing model for the four scenarios for 2013 data. Abbreviations are used as in Table 2.

\begin{tabular}{|c|c|c|c|c|c|c|c|c|c|c|}
\hline \multirow[b]{3}{*}{ Sampling day } & \multicolumn{4}{|c|}{$\delta^{2} \mathrm{H}(\% o)^{\mathrm{a}}$} & \multicolumn{6}{|c|}{$\mathrm{EC}\left(\mu \mathrm{S} \mathrm{cm}^{-1}\right)$} \\
\hline & \multicolumn{2}{|c|}{ Scenarios A and B } & \multicolumn{2}{|c|}{ Scenarios C and D } & \multicolumn{3}{|c|}{ Scenarios A and B } & \multicolumn{3}{|c|}{ Scenarios C and D } \\
\hline & $n$ & avg. & $n$ & avg. & $n$ & avg. & SD & $n$ & avg. & SD \\
\hline 23 May & & & 1 & -195.4 & & & & 1 & 15.3 & $(-) 0.1^{\mathrm{c}}$ \\
\hline 19 Jun & & & 7 & -160.1 & & & & 7 & 11.9 & 22.1 \\
\hline $16 \mathrm{Jul}$ & 7 & -1601 & 3 & -134.3 & 13 & 109 & 171 & 3 & 12.5 & 14.7 \\
\hline $\begin{array}{l}12 \mathrm{Aug} \\
11 \mathrm{Sept}^{\mathrm{b}} \\
18 \mathrm{Oct}^{\mathrm{b}}\end{array}$ & & & 2 & -139.9 & & & & 2 & 2.9 & 0.4 \\
\hline
\end{tabular}

a Because the isotopic composition of the high-elevation snowmelt end-member was derived by a regression (Eq. 11), the standard deviation was not computed. Thus, the computation of uncertainty was based on the standard error of the estimate of the regression $(6.0 \%)$ instead of the standard deviation of the samples averaged for each month. ${ }^{b}$ Because no snowmelt samples were collected in September and October, the August value was used also for the two sampling days in September and October. ${ }^{c}$ In May 2013, only one snowmelt sample was collected; therefore, no standard deviation could be computed, and the instrumental precision was used for the computation of the uncertainty of the estimated fractions.

for $100 \mathrm{~m}$ of elevation rise was derived from Eq. (13), and used to estimate the isotopic composition of high-elevation snowmelt from snowmelt samples collected monthly at different elevations from May to August 2013 (Table 4). Analogously, the average EC of snowmelt samples taken monthly was adopted.

In scenarios A and B, Eq. (13) was applied to snowmelt samples collected at different elevations (lower than $2800 \mathrm{~m}$ a.s.l.) in order to estimate the average isotopic composition of high-elevation snowmelt, and thus to define a temporally fixed end-member isotopic composition that was used in the calculations of streamflow-component fractions for each sampling date (Table 4, scenarios A and B). In scenarios $C$ and D, Eq. (13) was applied to snowmelt samples collected at different elevations (lower than $2800 \mathrm{~m}$ a.s.l.) and at different times of the melting season in order to estimate the seasonally variable isotopic compositions of highelevation snowmelt, which were used in the calculations of streamflow-component fractions for each sampling (Table 4, scenarios $\mathrm{C}$ and $\mathrm{D}$ ).

For all scenarios, the isotopic signature and EC of the glacier melt end-member was considered monthly variable (Table 5 and Sect. 4.1).

\section{Results}

\subsection{Isotopic composition and EC of the different water sources}

Snowmelt sampled from snow patches in summer 2012 and 2013 ranged in $\delta^{2} \mathrm{H}$ from -106.1 to $-139.5 \%$ and in EC from 3.2 to $77.0 \mu \mathrm{S} \mathrm{cm}^{-1}$. Glacier melt displayed a marked enrichment in heavy isotopes over summer, particularly in 2013 (Table 5). The spatial variability in the isotopic composition of glacier melt was generally small, with spatial
Table 5. Isotopic composition $\left(\delta^{2} \mathrm{H}\right)$ and EC of the glacier melt endmember used in the three-component mixing model for all scenarios for 2013 data. Abbreviations are used as in Table 2.

\begin{tabular}{|c|c|c|c|c|c|c|}
\hline \multirow[b]{2}{*}{ Sampling day } & \multicolumn{3}{|c|}{$\delta^{2} \mathrm{H}(\% \circ)$} & \multicolumn{3}{|c|}{$\mathrm{EC}\left(\mu \mathrm{Scm}^{-1}\right)$} \\
\hline & $n$ & avg. & SD & $n$ & avg. & SD \\
\hline $16 \mathrm{Jul}$ & 3 & -110.7 & 1.5 & 3 & 2.0 & 0.3 \\
\hline $12 \mathrm{Aug}$ & 2 & -104.2 & 3.8 & 2 & 2.2 & 0.7 \\
\hline $11 \mathrm{Sept}$ & 2 & -92.6 & 6.5 & 2 & 2.5 & 1.8 \\
\hline 18 Oct* $^{*}$ & 2 & -89.6 & 4.5 & 2 & 2.7 & 1.7 \\
\hline
\end{tabular}

* No samples were collected on 18 October, when the stream was sampled. Therefore, the tracer value of the glacier melt samples collected on 26 September was used in the mixing model calculations.

standard deviations ranging between 1.3 and $6.5 \%$. The EC of glacier melt was very low and little variable in space and in time (average: $2.1 \mu \mathrm{S} \mathrm{cm}^{-1}$; standard deviation: $0.7 \mu \mathrm{S} \mathrm{cm}^{-1}$; $n=16$ ) for 2012 and 2013 overall, even though a slight progressive increase in EC was observed in 2013 (Table 5).

The Saldur catchment was characterized by a marked variability of tracer signature within the same water compartment (i.e. main stream water, tributary water, groundwater) both in time and in space (Table 6, Figs. 2 and 3). There was a statistically significant difference in $\delta^{2} \mathrm{H}$ and EC between the Saldur River and its sampled tributaries for the entire sampling period (Mann-Whitney test with $p=0.004$ and $p<0.001$, respectively). On average, stream water showed more isotopically negative and variable values and had lower EC and higher variability in summer than in fall and winter. Moreover, the main stream had more depleted isotopic composition and lower EC compared to the tributaries (Table 6). Spring water was the most enriched water source during the fall but became more depleted compared to stream water during the summer when it also showed higher EC. The coeffi- 
Table 6. Basic statistics of isotopic composition $\left({ }^{2} \mathrm{H}\right)$ and EC of stream water in the Saldur catchment for data collected in the three sampling years. CV: coefficient of variation. The other abbreviations are used as in Table 2. Note that for simplicity the negative sign from the coefficient of variation of isotope data was removed.

\begin{tabular}{|c|c|c|c|c|c|c|c|}
\hline Period* & Statistic & $\begin{array}{r}\delta^{2} \mathrm{H} \\
\text { Saldur } \\
\text { River } \\
(\% 0)\end{array}$ & $\begin{array}{r}\delta^{2} \mathrm{H} \\
\text { tributaries } \\
(\% \circ)\end{array}$ & $\begin{array}{r}\delta^{2} \mathrm{H} \\
\text { springs } \\
(\% o)\end{array}$ & $\begin{array}{r}\text { EC } \\
\text { Saldur } \\
\text { River } \\
\left(\mu \mathrm{S} \mathrm{cm}^{-1}\right)\end{array}$ & $\begin{array}{r}\mathrm{EC} \\
\text { tributaries } \\
\left(\mu \mathrm{S} \mathrm{cm}^{-1}\right)\end{array}$ & $\begin{array}{r}\mathrm{EC} \\
\text { springs } \\
\left(\mu \mathrm{S} \mathrm{cm}^{-1}\right)\end{array}$ \\
\hline \multirow{4}{*}{ Entire period } & $n$ & 274 & 102 & 80 & 257 & 102 & 74 \\
\hline & avg. & -105.3 & -103.4 & -105.5 & 166.5 & 226.8 & 227.7 \\
\hline & $\mathrm{SD}$ & 5.2 & 4.9 & 6.1 & 57.1 & 104.0 & 77.8 \\
\hline & $\mathrm{CV}$ & 0.049 & 0.047 & 0.058 & 0.343 & 0.459 & 0.342 \\
\hline \multirow{4}{*}{ Summer } & $n$ & 240 & 81 & 68 & 223 & 81 & 62 \\
\hline & avg. & -105.9 & -104.5 & -107.0 & 153.7 & 218.5 & 229.7 \\
\hline & $\mathrm{SD}$ & 5.3 & 4.5 & 5.1 & 48.3 & 100.6 & 78.3 \\
\hline & $\mathrm{CV}$ & 0.050 & 0.043 & 0.048 & 0.314 & 0.460 & 0.341 \\
\hline \multirow{4}{*}{ Fall-winter } & $n$ & 34 & 21 & 12 & 34 & 21 & 12 \\
\hline & avg. & -101.1 & -99.2 & -96.9 & 250.7 & 258.8 & 217.2 \\
\hline & $\mathrm{SD}$ & 2.6 & 4.0 & 4.2 & 32.9 & 113.0 & 77.8 \\
\hline & $\mathrm{CV}$ & 0.026 & 0.040 & 0.044 & 0.131 & 0.437 & 0.358 \\
\hline
\end{tabular}

cient of variations of $\delta^{2} \mathrm{H}$ for groundwater were generally slightly higher than those for the stream water in all seasons, but the variability in EC was similar to that of the Saldur River and smaller than that of the tributaries (Table 6).

Overall, the median isotopic composition of stream water in the Saldur River varied slightly with location, but long error bars indicate a great temporal variability (Fig. 2). On the contrary, tributaries showed a wider range in the isotopic composition but a smaller temporal variability compared to the main stream (Fig. 2a). EC showed an increasing trend from upper to lower locations along the Saldur River (although with a slight interruption at S3-LSG) (Fig. 2b). Interestingly, T4 was the stream location with the most negative isotopic composition and highest EC. Groundwater tracer signature was overall intermediate between the main stream and the tributaries with a remarkable difference between SPR1-3 and SPR4.

Despite the strong variability, some spatial and temporal patterns can be observed (Fig. 3). For instance, all locations in June and early July 2012 showed isotopically depleted water and so did, overall, locations T4 and T5. Groundwater in SPR4 was constantly more enriched than in the other springs (Fig. 3a). The increasing trend in EC from the highest Saldur River location (S8) down to the lowest location (S1) in July and August of both years is also clearly visible, as well as the temporally constant and relatively very high EC of tributary water at T4 and very low EC of groundwater in SPR4 (Fig. 3b).

The mixing plot between $\delta^{2} \mathrm{H}$ and $\mathrm{EC}$ of stream water and groundwater of all sampling locations further highlights the differences in the tracer signature of the main stream, the tributaries and the springs (Fig. 4). Overall, the main stream showed a wider range in isotopic composition compared to the tributaries, in agreement with the long error bars of locations S1-S8 in Fig. 2. EC of the Saldur River was also more variable than EC in the other waters, except for T5 where plots separately compared to other tributaries and the main stream. The spring data points only partially overlap with the main stream data points: indeed, the tracer signal of the main stream water is upper-bounded by springs SPR1-3 and partially by T2-SG, and laterally, towards the less negative isotopic values, by SPR4. Only the tracer signal of T1, a left tributary flowing into the Saldur River a few hundred meters downstream of $\mathrm{S} 1$, lies within the main stream data, but samples were taken only in 2012 and therefore a robust comparison cannot be performed.

\subsection{Quantification of snowmelt and glacier melt in streamflow and associated uncertainty}

The results of the two- and three-component mixing models applied to 2013 data reveal a seasonally variable influence of snowmelt and glacier melt on streamflow, with estimated fractions generally decreasing from the highest to the lowest sampling location (Fig. 5). Overall, the proportion of snowmelt in stream water was comparable for the four sampling locations in August, September and October. Estimated snowmelt fractions were the highest on 19 June, up to $79 \pm 6 \%$ (scenario B) at S8. Field observations and MODIS data (Engel et al., 2016) revealed that the glacier surface was still covered with snow until the end of June. All four mix- 

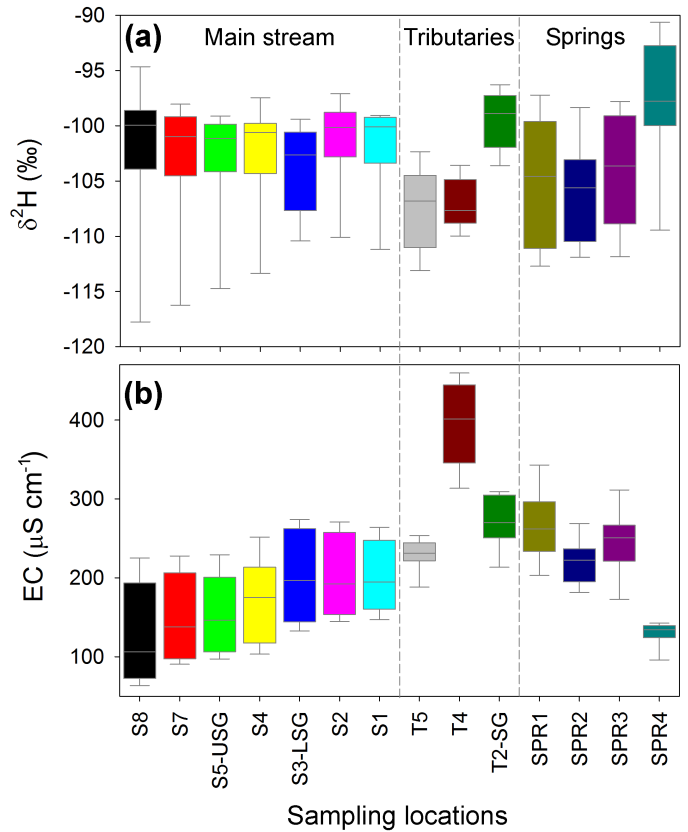

Figure 2. Box plot of $\delta^{2} \mathrm{H}$ (a) and EC (b) for samples taken on the same day at all locations in 2011 and $2012(n=10$ for all locations except for isotope data in T5 and for both tracers at SPR1, for which $n=9)$. Locations T1 and T3 are excluded because sampled only for 1 year. The boxes indicate the 25 th and 75 th percentile, the whiskers indicate the 10th and 90th percentile, the horizontal line within the box defines the median. In 2013, samples were collected only at some locations (Table 1) and therefore, for consistency, 2013 data are not reported here.

ing model scenarios agree with these observations and estimate no contribution of glacier melt to streamflow on the sampling days in May and June, and only partially on 18 October (Fig. 5). Glacier melt was an important component of streamflow on 16 July, especially according to scenarios A and $\mathrm{B}$, and dominated the streamflow in mid-August according to all scenarios, with peak estimates at $\mathrm{S} 8$ ranging from 50-66\% (scenario D) to 68-71\% (scenario A). On $12 \mathrm{Au}-$ gust, meltwater was the prevalent streamflow component at the three upper sampling locations and was still relevant at the lowest sampling location.

Overall, the four scenarios provide similar patterns of meltwater dynamics with higher similarities between scenarios A and B, and between scenarios C and D. Indeed, strong correlations exist between the estimates of the same component computed in each scenario, with $R^{2}$ for all possible combinations ranging between 0.91 and 0.997 for groundwater, 0.68 and 0.94 for snowmelt, and 0.74 and 0.94 for glacier melt ( $n=22, p<0.01$ for all correlations). Despite the general agreement, differences in the estimated streamflow components among the four scenarios do exist. Particularly, scenarios $\mathrm{C}$ and $\mathrm{D}$ yield higher overall proportions of snowmelt compared to scenarios $\mathrm{A}$ and $\mathrm{B}$, and scenarios $\mathrm{A}$ and D pro- vide the overall highest and smallest fraction of glacier melt, respectively. Furthermore, scenarios $C$ and D provide larger proportions of snowmelt and smaller proportions of glacier melt in July compared to the two other scenarios (Fig. 5). Overall, the uncertainty associated with the computation of the streamflow fractions is larger for scenarios $\mathrm{A}$ and $\mathrm{C}$ than for scenarios B and D (compare the length of error bars in Fig. 5).

It is worth mentioning that different proportions of meltwater components at the same stream location could be estimated according to the sampling time of the day. For the melt-induced runoff events sampled at high temporal resolution in 2011, 2012 and 2013 (Engel et al., 2016), the maximum contribution of meltwater to streamflow occurred at the streamflow peak or within an hour after the streamflow peak in $79 \%$ of the observations, whereas the maximum contribution of meltwater was observed within $2 \mathrm{~h}$ before the streamflow peak in the remaining $21 \%$ of the cases. Therefore, sampling several hours before or after the streamflow peak can lead to an underestimation of the meltwater fractions in streamflow (Fig. 6). However, the differences in meltwater fractions between samples collected at the streamflow peak and samples collected after the streamflow peak are lower and less variable (shorter error bars) than the ones computed before the streamflow peak (Fig. 6).

\subsection{Relation between the two tracers, streamflow and meltwater fractions}

The relation between $\delta^{2} \mathrm{H}$ and EC of stream water samples collected at S5-USG and S3-LSG on the same days in 2011, 2012 and 2013, and grouped by month, shows different behaviours according to the sampling period (Fig. 7). Overall, sampling days in May, June and September were characterized by lower mean daily temperatures and stream discharge, much higher EC and more depleted isotopic composition compared to sampling days in July and August (Table 7). The relation between the two tracers is statistically significant in the colder months, whereas it is more scattered and not statistically significant during the warmest months (Fig. 7). The range of $\delta^{2} \mathrm{H}$ values was slightly larger in the mid-summer period compared to May, June and September (16.7\%o vs. $15.1 \%$ ); on the contrary, the range of EC values was much larger in the spring-late summer period compared to July and August $\left(173.9 \mu \mathrm{S} \mathrm{cm}^{-1}\right.$ vs. $\left.77.1 \mu \mathrm{S} \mathrm{cm}^{-1}\right)$.

Streamflow during the summer-melt runoff events sampled hourly in 2011, 2012 and 2013 at the two monitored cross sections S5-USG and S3-LSG (Engel et al., 2016) is positively correlated with the fraction of meltwater (snowmelt plus glacier melt components) (Fig. 8). Streamflow is presented for comparison purposes both in terms of specific discharge and relative to bankfull discharge, the latter being estimated in the two reaches based on direct observations during high flows. A closer inspection of the figure reveals the occurrence of hysteretic loops between stream- 

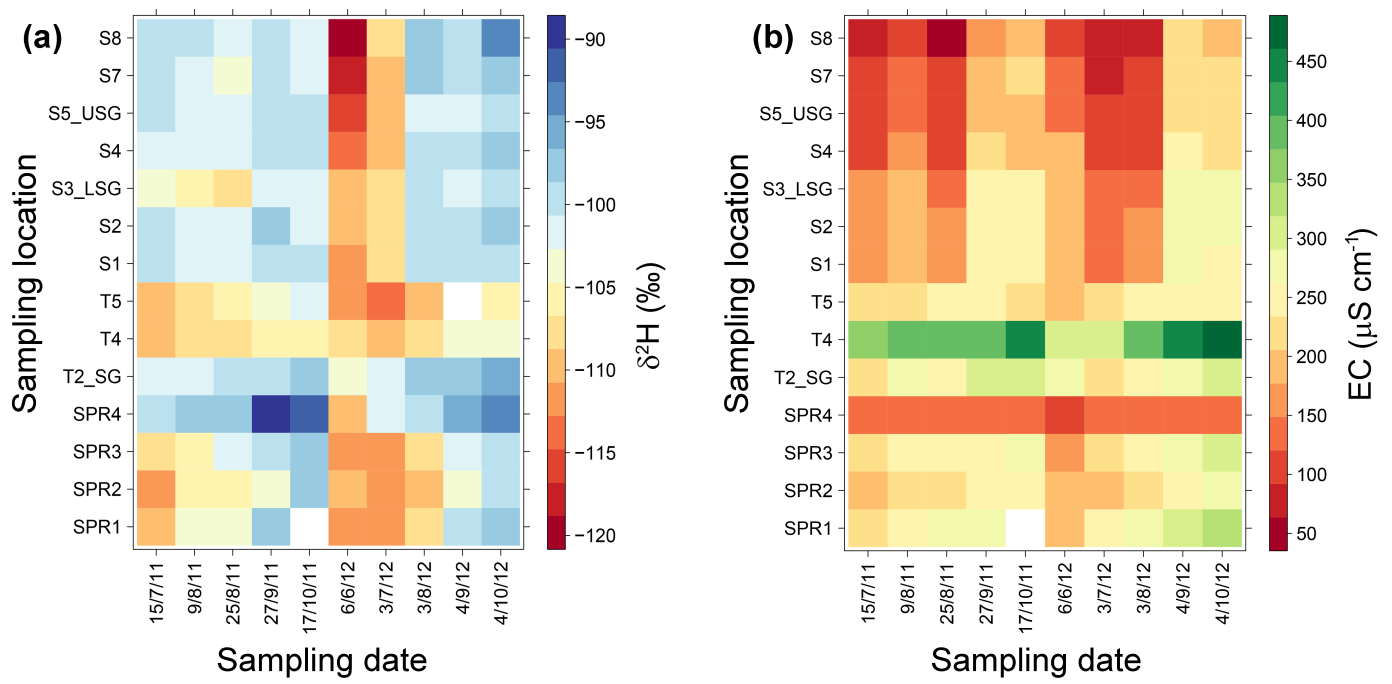

Figure 3. Spatio-temporal patterns of $\delta^{2} \mathrm{H}$ (a) and EC (b) for samples taken on the same day at all locations in 2011 and 2012 . Location T1 and T3 are excluded because sampled only for 1 year. White cells indicate no available measurements. In 2013, samples were collected only at some locations (Table 1) and therefore, for consistency, 2013 data are not reported here.

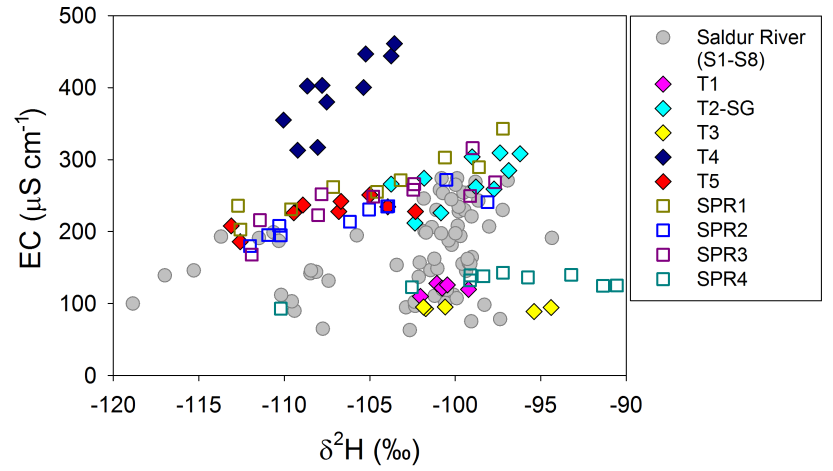

Figure 4. Relation between $\delta^{2} \mathrm{H}$ and $\mathrm{EC}$ at all locations in the main stream, the tributaries and the springs in 2011 and 2012. Data refer to samples collected at each location on the same days except for T1 and T3, where samples were taken for 1 year only (cf. Table 1). In 2013, samples were collected only at some locations (Table 1) and therefore, for consistency, 2013 data are not reported here.

flow and meltwater at both locations more evident for events on 12-13 July 2011, 10-11 August 2011 and 21-22 August 2013 at S5-USG, due to their magnitude. Nevertheless, a general positive trend between the two variables is observable, with meltwater fractions increasing when streamflow increased $\left(R^{2}=0.48, n=130 ; p<0.01\right.$ at S5-USG; $R^{2}=0.26, n=114 ; p<0.01$ at S3-LSG). The relation between meltwater fractions (computed as average of the results of the four mixing model scenarios) and streamflow is also plotted for the samples taken monthly in 2013, indicated by the stars in Fig. 8. The samples collected during the 2013 campaigns plot consistently with the samples taken during the melt-induced runoff events at both locations, overall agreeing with the positive trend of the meltwater-streamflow relation (Fig. 8).

\section{Discussion}

\subsection{Controls on the spatio-temporal patterns of the tracer signal}

Glacier melt was characterized by similar isotopic composition in 2012 and 2013 and, most of all, by a marked isotopic enrichment and a slight EC increase over the summer season (Table 5). Yde et al. (2016) showed similar trends in the isotopic composition of meltwater draining Mittivakkat Gletscher, Greenland, for two summers, and Zhou et al. (2014) reported an isotopic enrichment in the firn pack during the early melting season on a glacier in the Tibetan Plateau. However, other studies have reported a strong interannual variability in the isotopic signature of glacier melt (Yuanqing et al., 2001) or fairly consistent values over time (Cable et al., 2011; Maurya et al., 2011; Ohlanders et al., 2013; Racoviteanu et al., 2013). In our case, since melting of the surface ice determines no isotopic fractionation (Jouzel and Souchez, 1982), as confirmed by glacier melt samples falling on the local meteorological water line (Penna et al., 2014), the progressive enrichment could be explained by contributions from deeper portions of the glacier surface with increasing ablation over the melting season or sublimation of surface ice (Stichler et al., 2001). More data from this and other glacierized sites should be acquired to better assess this variability that we believe must be taken into account in the application of mixing models for the estimation of glacier melt contribution to streamflow in different seasons. 
Table 7. Basic statistics of specific discharge, $\delta^{2} \mathrm{H}$ and EC for the two groups reported in Fig. 7 for data collected in the three sampling years. Abbreviations are used as in Table 2.

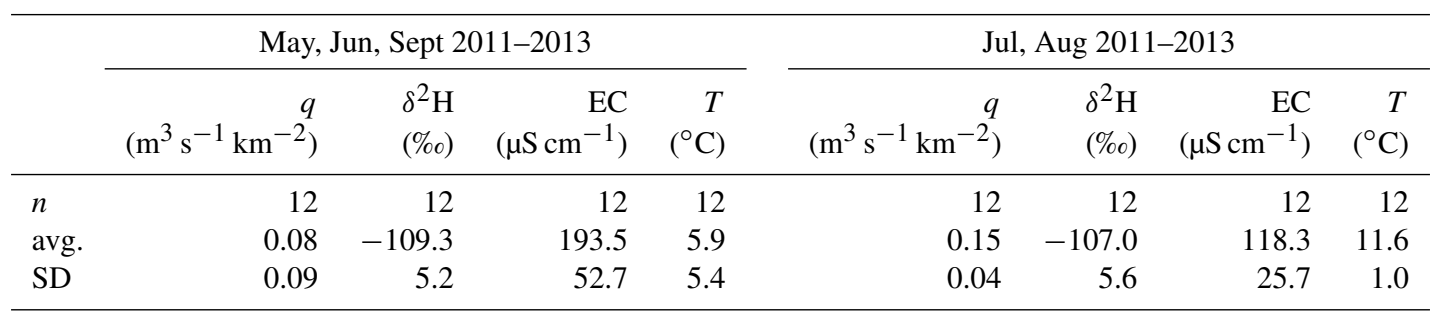

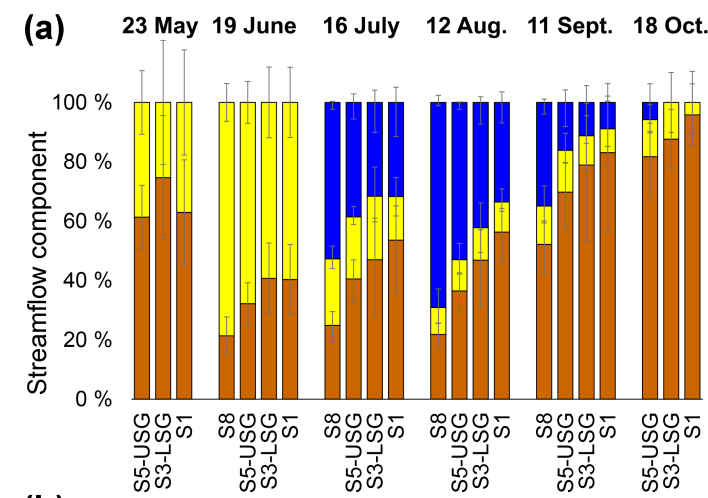

(b)
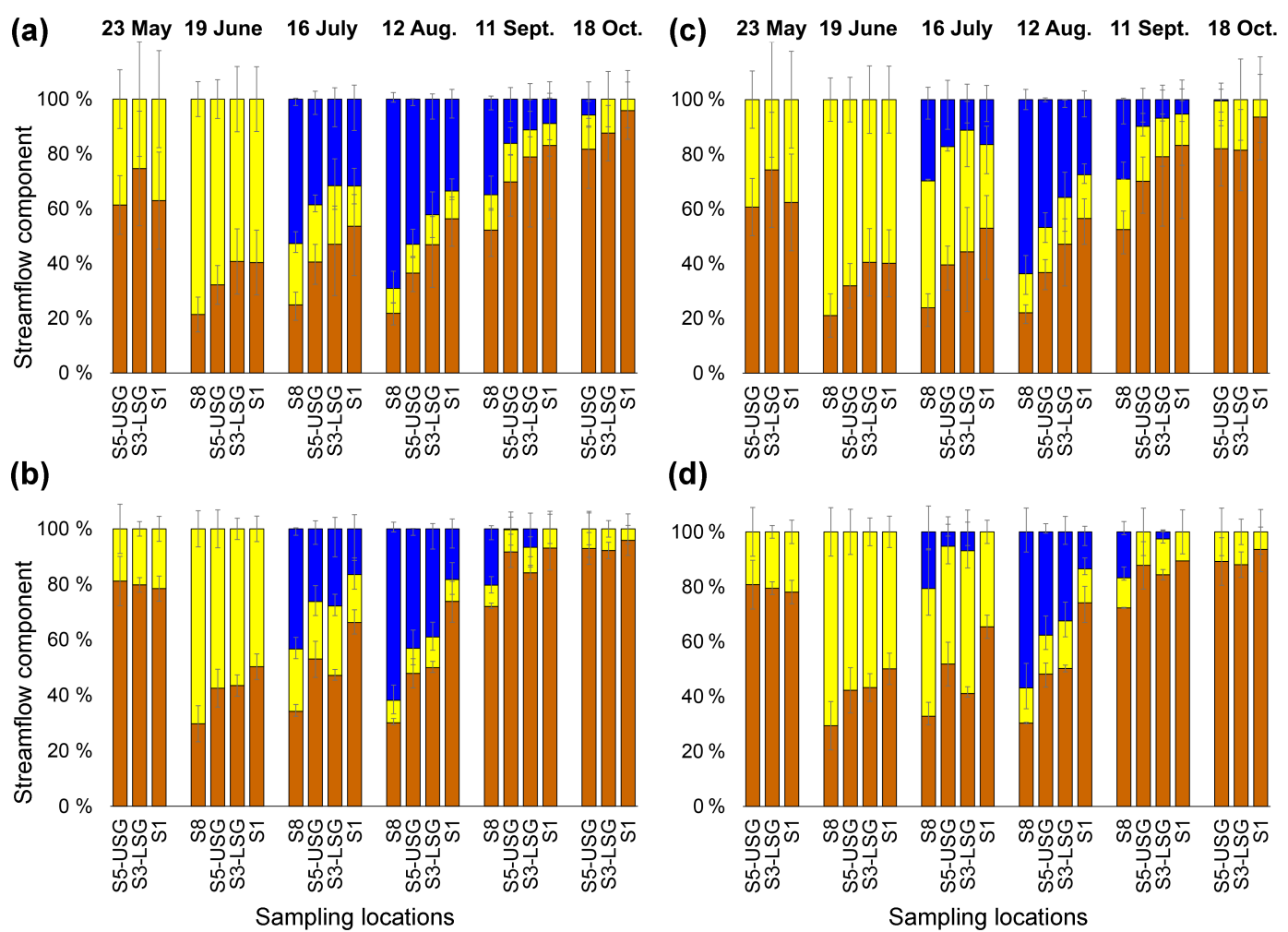

(d)

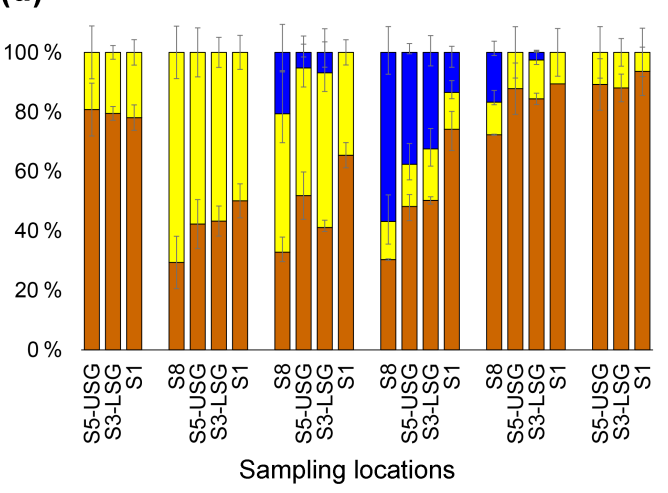

-Glacier melt

$\square$ Snowmelt

$\square$ Groundwater

Figure 5. Fractions of groundwater, snowmelt and glacier melt in streamflow for the six sampling days in 2013 at four cross sections along the Saldur River. Left column panels: the isotopic composition and EC of the snowmelt end-member was considered time invariant, and the groundwater end-member was based on spring data (scenario A, a) or on stream data (scenario B, b). Right column panels: the isotopic composition of the snowmelt end-member was considered monthly variable, and the groundwater end-member was based on spring data (scenario C, c) or on stream data (scenario D, d) during baseflow conditions. The error bars represent the statistical uncertainty for each component.

More negative $\delta^{2} \mathrm{H}$ values and lower EC observed in the Saldur River and in its tributaries during the summer than during the winter (Table 6) clearly indicate contributions of meltwater, namely snowmelt, typically isotopically depleted, and glacier melt, typically very diluted in solutes. However, differences exist in the tracer signal among the main stream and the tributaries. The much lower EC of the Saldur River in summer compared to the tributaries (Table 6) suggests important contributions of both snowmelt from high elevations and almost solute-free glacier melt to the main stream, but fewer glacier melt contributions to the tributaries. The larger difference of the coefficients of variation between summer and fall-winter in the Saldur River with respect to the tributaries (Table 6) confirms greater inputs of waters with contrasting isotopic signals (depleted snowmelt and more enriched glacier melt) but relatively similar low EC (Maurya et al., 2011). This observation is corroborated by the larger temporal variability (longer error bars) in the isotopic com- 


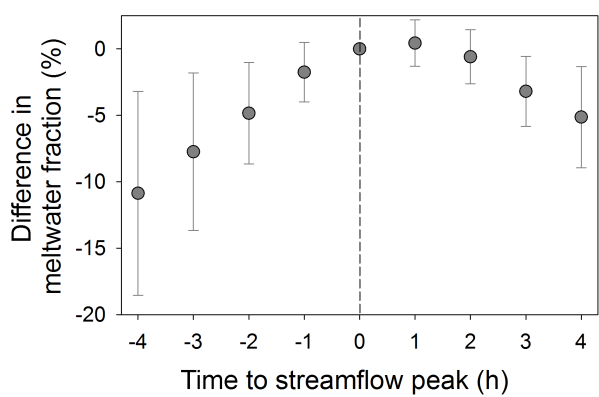

Figure 6. Average difference between the meltwater fraction in streamflow at the time of streamflow peak and the meltwater fraction at different hours from the time of streamflow peak for the meltinduced runoff events at S5-USG and S3-LSG in 2011-2013. Error bars represent the standard deviation. The vertical line indicates the time of streamflow peak.

position of the main stream compared to the tributaries, by the similar temporal variability in EC (expressed by the similar length of error bars in Fig. 2), and by the larger span of $\delta^{2} \mathrm{H}$ values in the main stream compared to the tributaries visible in the mixing plot (Fig. 4).

The same isotopic composition of the Saldur River and the springs (Table 6, despite the lack of temporal consistency) and the partial overlap of the spring data points with the stream data points in the mixing plot (Fig. 4) suggest connectivity between the main stream and shallow groundwater, in agreement with observations in other glacierized catchments (Hindshaw et al., 2011; Magnusson et al., 2014). However, a large spatio-temporal variability in the tracer signal of springs was observed (Fig. 2-4) highlighting the complex hydrochemistry of the groundwater system (Brown et al., 2006; Hindshaw et al., 2011; Kong and Pang, 2012). The depleted signal in summer months (Table 6) suggests a role of snowmelt in groundwater recharge (Baraer et al., 2015; Fan et al., 2015; Xing et al., 2015) that was quantified in a previous study (Penna et al., 2014). At the same time, the relatively high EC during summer demonstrates solute concentration and suggests longer residence times and/or flow pathways (and thus long contact with the soil particles) of infiltrating meltwater before recharging the groundwater (Brown et al., 2006; Esposito et al., 2016). The similar coefficients of variations of the two tracers in summer and fall indicate fewer inter-seasonal differences in water inputs to the springs compared to the streams and suggest continuous groundwater recharge even at the end of the melting seasons, pointing out again to relatively long travel times and recharge times.

We mainly attribute the large spatial and temporal variability of tracers in stream water and groundwater to the control exerted by climate (seasonality), topography and geological settings. For instance, the depleted waters at all locations in June and early July 2012 (Fig. 3a) indicate heavy snowmelt contributions, consistent with the results of the mixing models (Fig. 5), clearly reflecting a climatic control (snow ac-

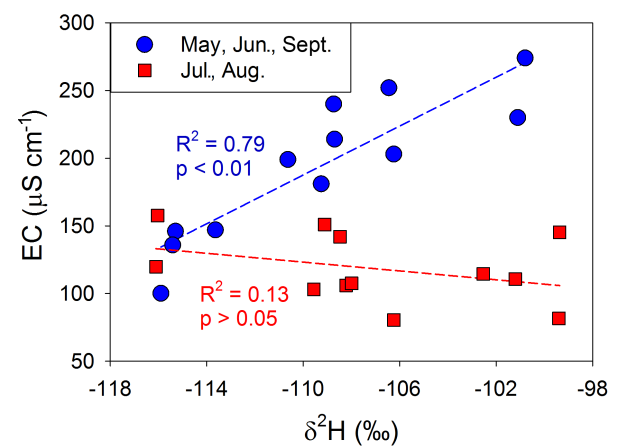

Figure 7. Relation between $\delta^{2} \mathrm{H}$ and EC of samples collected at S5-USG and S3-LSG on the same days in 2011, 2012 and 2013, grouped by month.

cumulation during the winter-early spring and subsequent melting). The increasing trend in EC from S8 to S1 during summer periods (Fig. 3b), consistent with other works (Kong and Pang, 2012; Fan et al., 2015), reflects the combined effect of lower elevations, smaller snow-covered area, decreasing glacierized area, progressive decrease of meltwater fractions and proportional increase of groundwater contributions (Fig. 5), and inflows by groundwater-dominated lateral tributaries.

The more depleted median isotopic composition and the higher EC of S3-LSG (Fig. 2) reflected the influence of the tributary T4, a few tens of meters upstream of S3-LSG that had a depleted signal and very high EC and that plotted separately in the mixing diagram (Fig. 4). A combination of depleted isotopic composition (typical of snowmelt) and high EC (typical of groundwater) was very rare in the catchment, and we do not have evidence to explain the origin of tributary T4 and the reason of its tracer signature. Analogously, our data did not provide robust explanations about the more enriched isotopic composition and the constantly much lower EC of SPR4 compared to other springs (Figs. 3 and 4). Ongoing and future analyses of major anions and cations will help to shed some light on the origin of T4 and SPR4.

\subsection{Seasonal control on the $\delta^{2} \mathrm{H}-\mathrm{EC}$ relation and on meltwater fractions}

As observed elsewhere (e.g. Hindshaw et al., 2011; Maurya et al., 2011; Blaen et al., 2014), streamflow in the main stream increased during melting periods, EC decreased due to the dilution effect and the isotopic composition generally shifted towards depleted values reflecting the meltwater signal. However, the two tracers were strongly correlated only in May, June and September (Fig. 7), when glacier melt was negligible or absent (Fig. 5), because the tracer signal in the stream reflected the low EC and the depleted isotopic composition of snowmelt. Conversely, during mid-summer, when glacier melt significantly contributed to streamflow (Fig. 5), the relation between the two tracers became weak (Fig. 7), 


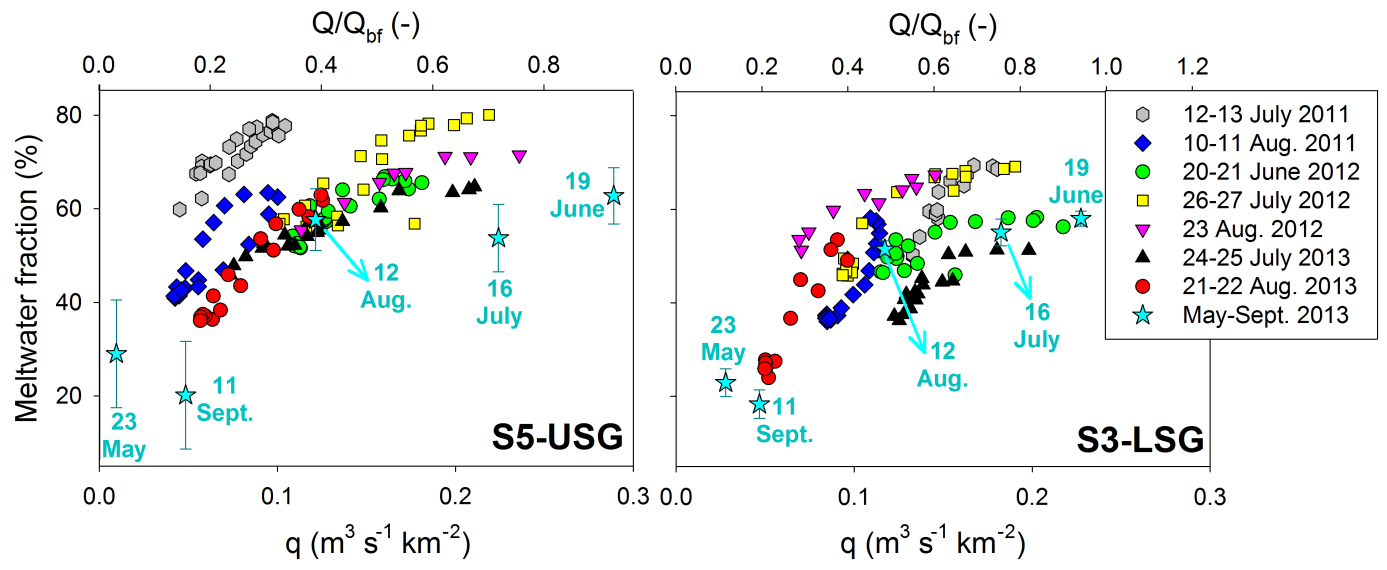

Figure 8. Relation between specific discharge $(q)$ and meltwater fraction (\%) in streamflow for the melt-induced runoff events in 2011,2012 and 2013 sampled at hourly timescale (represented by different coloured symbols), and for the monthly sampling days in 2013 at S5-USG and S3-LSG (represented by stars in cyan). Meltwater fractions for the melt-induced runoff events were taken from Engel et al. (2016), while meltwater fractions for the monthly sampling days in 2013 are given by the average of the four different mixing models scenarios (presented in Fig. 5), and error bars indicate the standard deviation. For the double-peak event on 23-24 August 2012 at S5-USG, where a $9 \mathrm{~mm}$ rainstorm superimposed the melt event (cf. Engel et al., 2016), only the melt-induced part of the event was considered. Discharge is reported also as fraction of the bankfull discharge $Q_{\mathrm{bf}}$ at the two sections.

because glacier melt had very low EC but was not as isotopically depleted as snowmelt. Having multiple tracers is of certain usefulness when investigating water sources and mixing processes (Barthold et al., 2011), especially in highly heterogeneous environments (Hindshaw et al., 2011), and is essential for the identification of various streamflow components. However, it is important to know the periods when only one tracer could be reliably used, at least for assessing meltwater inputs, especially in glacierized catchments where logistical constraints are always challenging.

The hysteretic behaviour observed between streamflow and meltwater fraction for the melt-induced runoff events (Fig. 8) reflects the hysteresis observed in the relation between streamflow and EC (Engel et al., 2016), suggesting contributions from water sources characterized by different temporal dynamics (Dzikowski and Jobard, 2012). The combination of the highest streamflow and the highest meltwater proportion was obtained at both stream sections in June due to the remarkable contribution of meltwater from the relatively deep snowpack in the upper part of the catchment. It is worth highlighting how the meltwater fraction can frequently represent a substantial $(>50 \%)$ proportion of the bankfull discharge, both during snow and glacier melt flows. This implies that the expected progress of glacier shrinking and future changes in both runoff components will likely have important consequences for the morphological configuration of high-elevation streams like the Saldur River, especially in the wider, braided reaches more responsive to variations in water and sediment fluxes (Wohl, 2010).

\subsection{Role of snowmelt and glacier melt on streamflow}

The spatial and temporal patterns of meltwater dynamics are consistent with those estimated in other high-elevation catchments worldwide. For instance, the dominant role of snowmelt in late spring-early summer and of glacier melt later in summer was observed across different sites in Asia, North America, South American and Europe (Aizen et al., 1996; Cable et al., 2011; Ohlanders et al., 2013; Blaen et al., 2014, respectively). The decreasing contribution of meltwater from the upper to the lower stream locations from June to October shown almost consistently by all scenarios (Fig. 5) is related to the increasing distance from the glacier and catchment size, and decreasing elevation, in agreement with results from other sites (Cable et al., 2011; Prasch et al., 2013; Racoviteanu et al., 2013; Marshall, 2014). Moreover, lateral contributions from non-glacier-fed tributaries and/or tributaries dominated by groundwater increased the groundwater fraction in streamflow as well and proportionally decreased the meltwater fraction (Marshall, 2014; Fan et al., 2015).

Our estimates of snowmelt contribution to streamflow during the melting season are consistent with those reported in other studies (Carey and Quinton, 2004; Mukhopadhyay and Khan, 2015) and with those found in the same catchment during individual runoff events (Engel et al., 2016). It is more difficult to compare our computed fractions of glacier melt in stream water with estimates in other sites because they can be highly dependent on the yearly climatic variability, on the proportion of glacierized area in the catchment and because they are usually reported at the monthly or yearly scale. However, when considering the total meltwater contribution, the computed fractions for the June-August period 
agree reasonably well with those recently estimated at the seasonal scale in other high-elevation catchments by $\mathrm{Pu}$ et al. (2013) (41-62, $12 \%$ of glacierized area), Fan et al. (2015) (26-69\%), Xing et al. (2015) (almost $60 \%$ ) and at the annual scale by Jeelani et al. (2016) (52, $3 \%$ of glacierized area), and are even higher than those computed by Mukhopadhyay and Khan (2015) (25-36\%). These observations stress the importance of water resources stored within the cryosphere even in catchments with limited extent of glacierized area, such as the Saldur catchment.

Overall, our tracer-based results on the influence of snowmelt and glacier melt on streamflow agree with glacier mass balance results, which revealed important losses from the glacier surface $(-428 \mathrm{~mm}$ in snow water equivalent) for the year 2012-2013 (Galos and Kaser, 2013). Particularly, the first strong heat wave serving as melting input was observed in mid-June, when the glacier was still covered by snow and no glacier melt occurred (Galos and Kaser, 2013), in agreement with our estimates of snowmelt contributions (Fig. 5). Glaciological results also showed that most of the glacier mass loss occurred at the end of July to midAugust 2013, but glacier ablation in the lower part of the glacier (below $3000 \mathrm{~m}$ a.s.l.) was observed until the beginning of October (Galos and Kaser, 2013), corroborating our tracer-based estimates (Fig. 5).

\subsection{Sources of uncertainties in the estimated streamflow components}

Various sources of uncertainty affect the estimate of the streamflow components when using mixing models in complex environments such as mountain catchments (Uhlenbrook and Hoeg, 2003; Ohlanders et al., 2013). In cases of mixing model applications to separate snowmelt from glacier melt and groundwater, thus not considering rainfall, and in the case of no availability of streamflow measurements (in our case at S8 and S1), uncertainty can be mainly ascribed to the precision of the instrument used for the determination of the tracer signal, and the spatio-temporal patterns of the end-member tracer signature. The instrumental precision can be relatively easily taken into account and quantified by adopting statistically based procedures (e.g. Genereux, 1998). However, the spatio-temporal variation in the hydrochemical signal of the end-members is more challenging to capture and can provide the largest source of uncertainty (Uhlenbrook and Hoeg, 2003; Pu et al., 2013). The isotopic composition and EC of shallow groundwater emerging from springs can be very different within a catchment, especially in cases of heterogeneous geology, as well as the tracer signature of streams at different locations even during baseflow conditions (Jeelani et al., 2010, 2015). Indeed, in our case, the highest uncertainty in the estimated component fractions provided by scenarios $\mathrm{A}$ and $\mathrm{C}$ can likely be ascribed to the spatial variability of the tracer signature of the sampled springs.
The isotopic composition of snowmelt can mainly change according to (i) macro-topography (e.g. aspect determines different melting rates and so different isotopic compositions); (ii) micro-topography, because small hollows tend to host "older" snow with a more enriched isotopic composition compared to sloping areas; (iii) elevation; and (iv) season, with $\delta$ values becoming more negative with increasing elevation and more positive over the melting season (Uhlenbrook and Hoeg, 2003; Holko et al., 2013; Ohlanders et al., 2013). EC of snow, and therefore, snowmelt can change as well due, for instance, to the ionic pulse at the beginning of the melting season (Williams and Melack, 1991) and/or reflecting seasonal inputs of impurities from the atmosphere (Li et al., 2006), although this variability is usually much more limited compared to that of the isotopes.

In our case, the instrumental precision of the isotope analyser and the EC meter is relatively low and was entirely taken into account by the statistical assessment of uncertainty we applied. The spatio-temporal variability of snowmelt was addressed by sampling snowmelt at different elevations, aspects and times of the seasons. Finally, we observed very limited spatial patterns but a marked seasonal change in the tracer signature of glacier melt (Table 5) that was taken into account in the mixing model application (Table 2). Despite these efforts, logistical issues related to the size of the catchment as well as practical and safety issues related to the accessibility of most areas of the catchment, not only in winter, and, not last, economical issues prevent a very detailed characterization and quantification of all sources of uncertainty associated with the estimates of the streamflow components at different times of the year and different stream locations. In addition, an underestimation of meltwater fractions due to sampling time not always corresponding to the streamflow peak should be considered (Fig. 6). Specifically, the samples taken on 19 June at S5-USG and S3-LSG were collected almost $4 \mathrm{~h}$ before the streamflow peak. This means that an additional contribution of snowmelt almost up to $20 \%$ could be expected (Fig. 6). As far as we know, these results have not been reported elsewhere and are critical for a proper assessment of the uncertainty in the estimated component fractions. Moreover, these observations suggest that adequate sampling strategies are critical (Uhlenbrook and Hoeg, 2003) and must be considered when planning field campaigns aiming at the quantification of meltwater in glacierized catchments.

\subsection{Conceptual model of streamflow components dynamics}

The findings from our two previous studies (Penna et al., 2014; Engel et al., 2016) and from the present work allow us to derive a conceptual model of streamflow and tracer response to meltwater dynamics in the Saldur catchment (Fig. 9). To the best of our knowledge, this is the first study to present such a conceptual model of streamflow-component dynamics. Although intuitive, this conceptualization is im- 

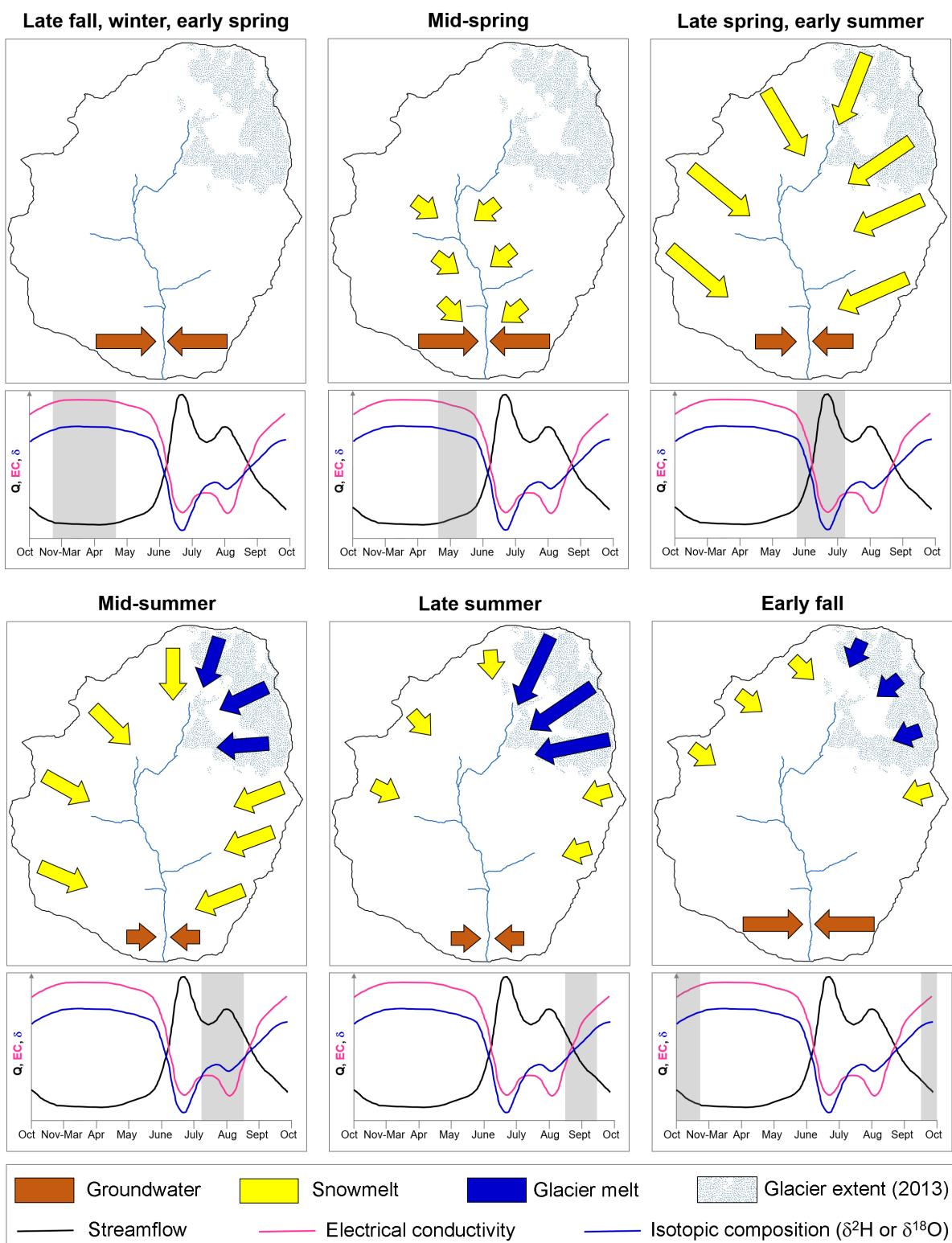

Snowmelt

Glacier melt

Glacier extent (2013)

Electrical conductivity

Isotopic composition $\left(\delta^{2} \mathrm{H}\right.$ or $\left.\delta^{18} \mathrm{O}\right)$

Figure 9. Conceptual model of the seasonal evolution of streamflow contributions in the Saldur River catchment (closed at LSG). The top subplots in each panel represent the water contributions to streamflow, and the size of the arrows is roughly proportional to the intensity of water fluxes. The bottom subplots show a sketch hydrograph along with EC and isotopic composition of stream water, and the shaded areas indicate time periods corresponding to the top subplots. The winter months, approximately between November and March, when the catchment is in a quiescent state and no significant hydrological dynamics is assumed to occur, are compacted in order to give more space to the other seasons.

portant because it represents a paradigm that, given the characteristics of the study site, can be applied to many other glacierized catchments worldwide.

During late fall, winter and early spring, precipitation mainly falls in form of snow, streamflow reaches its minimum and is predominantly formed by baseflow. EC in stream water is highest and the isotopic composition is relatively enriched, reflecting the groundwater signal. In mid-spring the melting season begins. The snowpack starts to melt at the lower elevations in the catchment and the snow line progressively moves upwards; stream water EC begins to decrease due to the dilution effect and $\delta$ values become more negative, reflecting the first contribution of snowmelt (19-39\%). In late spring and early summer the combination of relatively high radiation inputs and still deep snowpack in the middle and upper portion of the catchment provides maximum snowmelt contributions to streamflow (up to $79 \pm 6 \%$ in the Saldur River at the highest sampling location) which is 
characterized by marked diurnal fluctuations and the highest melt-induced peaks. Groundwater fractions in stream water become proportionally smaller. The glacier surface is still totally snow covered; thus, glacier melt does not appreciably contribute to streamflow. EC is very low due to the strong dilution effect and the isotopic composition is most depleted. In mid-summer the snowpack is present only at the highest elevations and the glacier surface is mostly snow free, so that a combined role of snowmelt and glacier melt occurs. Streamflow is characterized by important diurnal fluctuations, but melt-induced peaks tend to be smaller in absolute values than in early summer associated with snowmelt. Although the snowmelt contribution has decreased, EC in the main stream is still very low due to the input of the extremely low EC of glacier melt. On the contrary, the stream water isotopic composition is less depleted compared to late spring and early summer due to the relatively more enriched signal of glacier melt with respect to snowmelt. In late summer snow disappears from most of the catchment and is only limited to residual patches in sheltered locations. The most important inputs to streamflow are provided by glacier melt that reaches its largest contributions (up to $68-71 \%$ in the highest monitored Saldur River location). Diurnal fluctuations are still clearly visible but the decreasing radiation energy combined with lower melting supply limits high flows. EC begins to decrease and the isotopic composition to increase. From late spring to late summer low-intensity rainfall events provide limited contributions to streamflow. However, rainfall events of moderate or relatively high intensity can occur so that rain-induced runoff superimposes the melt-induced runoff and produces the highest observed streamflow peaks. In early fall, meltwater contributions are limited to snowmelt from early snowfalls at high elevations and residual glacier melt and the groundwater proportions become progressively more important. Streamflow decreases significantly and only small diurnal fluctuations are observable during clear days. The two tracers slowly return to their background values.

\section{Conclusions and future perspectives}

Our tracer-based studies (water isotopes and EC) in the Saldur catchment aimed to investigate the water sources variability and the contribution of snowmelt, glacier melt and groundwater to streamflow in order to contribute to a better comprehension of the hydrology of high-elevation glacierized catchments. We highlighted the highly complex hydrochemical signature of water in the catchment and the main controls on such variability. We applied mixing models to estimate the fractions of meltwater in streamflow over a season, not only at the catchment outlet as usually performed in other studies but also at different locations along the main stream. We found that snowmelt dominated the hydrograph in late spring-early summer, with fractions ranging between $50 \pm 5$ and $79 \pm 6 \%$ at different stream locations and accord- ing to different model scenarios that took into account the spatial and temporal variability of end-member tracer signature. Glacier melt was a remarkable streamflow component in August, with maximum contributions ranging between 815 and $68-71 \%$ at different stream locations and according to different scenarios. These estimates underline the key role of snowpack and glaciers on streamflow and stress their strategic importance as water resources.

From a methodological perspective, our results showed that during mixed snowmelt and glacier melt periods, EC and isotopes were not correlated due to the different tracer signature of the two sources of meltwater, whereas they provided a consistent pattern during snowmelt periods only. Such a behaviour, which we found hardly reported elsewhere, should be better assessed over longer time spans and in other sites, but suggests possible simplified monitoring strategies in snow-dominated catchments or during snowmelt periods in glacierized catchments. We identified the main sources of uncertainty in the computed estimates of streamflow components, mainly related to the spatio-temporal variability of the end-member tracer signature, including a clear seasonal enrichment of glacier melt isotopic composition. This is a pattern that must be considered when applying mixing models on a seasonal basis and that we invite to investigate in other glacierized environments. Furthermore, this is the first study, to our knowledge, which quantified the possible underestimation of meltwater fractions in streamflow occurring when stream water is sampled far from the streamflow peak during melt-induced runoff events. Again, this raises awareness about the need for careful planning of tracer-based field campaigns in high-elevation catchments.

We developed a perceptual model of meltwater dynamics and associated streamflow and tracer response in the Saldur catchment that likely applies to many other glacierized catchments worldwide. However, some limitations intrinsic in our approach should be considered. For instance, the reduced number of rain water samples collected at the rainfallevent scale over the 3 years did not allow us to fully assess the seasonal role of precipitation on streamflow in relation to meltwater. Furthermore, the use of EC, which integrates all water solutes in a single measurement, cannot differentiate well some water sources and their relation with the underlying geology. Finally, the monthly sampling resolution at different locations is useful to obtain a general overview and first estimates of the seasonal variability of streamflow components but high-frequency sampling can certainly help to capture finer hydrological dynamics. In this context, the results of the present work can serve as a very useful basis for modelling applications, particularly to constrain the model parametrization and to reduce the simulation uncertainties, and therefore to obtain more reliable predictions of streamflow dynamics and meltwater contributions to streamflow in high-elevation catchments. 


\section{Data availability}

Hydrometeorological data from the Mazia Valley are available from the LTESR Mazia website (http://lter.eurac.edu/) upon request trough the DEIMS (Drupal Ecological Information System) meta-database (https://data.lter-europe. net/deims/site/LTER_EU_IT_097/). Tracer data used in this study are freely available by contacting the authors.

Acknowledgements. This work was supported by the research projects "Effects of climate change on high-altitude ecosystems: monitoring the Upper Match Valley" (Foundation of the Free University of Bozen-Bolzano), "EMERGE: Retreating glaciers and emerging ecosystems in the southern Alps" (Dr. Erich Ritterund Dr. Herzog-Sellenberg-Stiftung im Stifterverband für die Deutsche Wissenschaft) and partly by the project "HydroAlp", financed by the Autonomous Province of Bozen-Bolzano. We thank the Dept. of Hydraulic Engineering and Hydrographic Office of the Autonomous Province of Bozen-Bolzano for their technical support, G. Niedrist (EURAC) for maintaining the meteorological stations, Giulia Zuecco (University of Padova, Italy) for the isotopic analyses and Stefan Galos (University of Innsbruck, Austria) for sharing glacier mass balance results. The site Matsch/Mazia belongs to the national and international long-term ecological research networks (LTER-Italy, LTER Europe and ILTER).

Edited by: M. Hrachowitz

Reviewed by: two anonymous referees

\section{References}

Aizen, V. B, Aizen, E. M., and Melack, J. M.: Precipitation, melt and runoff in the northern Tien Shan, J. Hydrol., 186, 229-251, 1996.

Baraer, M., McKenzie, J., Mark, B. G., Gordon, R., Bury, J., Condom, T., Gomez, J., Knox, S., and Fortner, S. K.: Contribution of groundwater to the outflow from ungauged glacierized catchments: a multi-site study in the tropical Cordillera Blanca, Peru, Hydrol. Process., 29, 2561-2581, doi:10.1002/hyp.10386, 2015.

Barthold, F. K., Tyralla, C., Schneider, K., Vaché, K. B., Frede, H.G., and Breuer, L.: How many tracers do we need for end member mixing analysis (EMMA)? A sensitivity analysis, Water Resour. Res., 47, W08519, doi:10.1029/2011WR010604, 2011.

Beniston, M.: Impacts of climatic change on water and associated economic activities in the Swiss Alps, J. Hydrol., 412-413, 291296, doi:10.1016/j.jhydrol.2010.06.046, 2012.

Blaen, P. J., Hannah, D. M., Brown, L. E., and Milner, A. M.: Water source dynamics of high Arctic river basins: water source dynamics of high arctic river basins, Hydrol. Process., 28, 35213538, doi:10.1002/hyp.9891, 2014.

Brown, L. E., Hannah, D. M., Milner, A. M., Soulsby, C., Hodson, A. J., and Brewer, M. J.: Water source dynamics in a glacierized alpine river basin (Taillon-Gabiétous, French Pyrénées): alpine basin water source dynamics, Water Resour. Res., 42, W08404, doi:10.1029/2005WR004268, 2006.

Cable, J., Ogle, K., and Williams, D.: Contribution of glacier meltwater to streamflow in the Wind River Range, Wyoming, inferred via a Bayesian mixing model applied to isotopic measurements, Hydrol. Process., 25, 2228-2236, doi:10.1002/hyp.7982, 2011.

Carey, S. K. and Quinton, W. L.: Evaluating snowmelt runoff generation in a discontinuous permafrost catchment using stable isotope, hydrochemical and hydrometric data, Nord. Hydrol., 35, 309-324, 2004.

Carey, S. K. and Quinton, W. L.: Evaluating runoff generation during summer using hydrometric, stable isotope and hydrochemical methods in a discontinuous permafrost alpine catchment, Hydrol. Process., 19, 95-114, doi:10.1002/hyp.5764, 2005.

Carturan, L., Zuecco, G., Seppi, R., Zanoner, T., Borga, M., Carton, A., and Dalla Fontana, G.: Catchment-scale permafrost mapping using spring water characteristics, Permafrost Periglac. Process., 27, 253-270, doi:10.1002/ppp.1875, 2016.

Dzikowski, M. and Jobard, S.: Mixing law versus discharge and electrical conductivity relationships: application to an alpine proglacial stream, Hydrol. Process., 26, 2724-2732, doi:10.1002/hyp.8366, 2012.

Engel, M., Penna, D., Bertoldi, G., Dell'Agnese, A., Soulsby, C., and Comiti, F.: Identifying run-off contributions during meltinduced run-off events in a glacierized alpine catchment, Hydrol. Process., 30, 343-364, doi:10.1002/hyp.10577, 2016.

Engelhardt, M., Schuler, T. V., and Andreassen, L. M.: Contribution of snow and glacier melt to discharge for highly glacierised catchments in Norway, Hydrol. Earth Syst. Sci., 18, 511-523, doi:10.5194/hess-18-511-2014, 2014.

Esposito, A., Engel, M., Ciccazzo, S., Daprà, L., Penna, D., Comiti, F., Zerbe, S., and Brusetti, L.: Spatial and temporal variability of bacterial communities in high alpine water spring sediments, Res. Microbiol., 167, 325-333, doi:10.1016/j.resmic.2015.12.006, 2016.

Fan, Y., Chen, Y., Li, X., Li, W., and Li, Q.: Characteristics of water isotopes and ice-snowmelt quantification in the Tizinafu River, north Kunlun Mountains, Central Asia, Quatern. Int., 380-381, 116-122, doi:10.1016/j.quaint.2014.05.020, 2015.

Finger, D., Hugentobler, A., Huss, M., Voinesco, A., Wernli, H., Fischer, D., Weber, E., Jeannin, P.-Y., Kauzlaric, M., Wirz, A., Vennemann, T., Hüsler, F., Schädler, B., and Weingartner, R.: Identification of glacial meltwater runoff in a karstic environment and its implication for present and future water availability, Hydrol. Earth Syst. Sci., 17, 3261-3277, doi:10.5194/hess-173261-2013, 2013

Fischer, B. M. C., Rinderer, M., Schneider, P., Ewen, T., and Seibert, J.: Contributing sources to baseflow in pre-alpine headwaters using spatial snapshot sampling, Hydrol. Process., 29, 5321-5336, doi:10.1002/hyp.10529, 2015.

Galos, S. and Kaser, G.: The mass balance of Matscherferner 2012/13, Report of the research project "A physically based regional mass balance approach for the glaciers of Vinschgau - glacier contribution to water availability", funded by the Autonomous Province of Bozen-Bolzano, Italy, 2013.

Genereux, D.: Quantifying uncertainty in tracer-based hydrograph separations, Water Resour. Res., 34, 915-919, doi:10.1029/98WR00010, 1998.

Hindshaw, R. S., Tipper, E. T., Reynolds, B. C., Lemarchand, E., Wiederhold, J. G., Magnusson, J., Bernasconi, S. M., Kretzschmar, R., and Bourdon, B.: Hydrological control of stream water chemistry in a glacial catchment 
(Damma Glacier, Switzerland), Chem. Geol., 285, 215-230, doi:10.1016/j.chemgeo.2011.04.012, 2011.

Hoeg, S., Uhlenbrook, S., and Leibundgut, C.: Hydrograph separation in a mountainous catchment - combining hydrochemical and isotopic tracers, Hydrol. Process., 14, 11991216, doi:10.1002/(SICI)1099-1085(200005)14:7<1199::AIDHYP35>3.0.CO;2-K, 2000.

Holko, L., Danko, M., Dóša, M., Kostka, Z., Šanda, M., Pfister, L., and Iffly, J. F.: Spatial and temporal variability of stable water isotopes in snow related hydrological processes, Bodenkultur, 39, 3-4, 2013.

Jeelani, G., Bhat, N. A., and Shivanna, K.: Use of $\delta^{18} \mathrm{O}$ tracer to identify stream and spring origins of a mountainous catchment: A case study from Liddar watershed, Western Himalaya, India, J. Hydrol., 393, 257-264, doi:10.1016/j.jhydrol.2010.08.021, 2010.

Jeelani, G., Kumar, U. S., Bhat, N. A., Sharma, S., and Kumar, B.: Variation of $\delta^{18} \mathrm{O}, \delta \mathrm{D}$ and ${ }^{3} \mathrm{H}$ in karst springs of south Kashmir, western Himalayas (India), Hydrol. Process., 29, 522-530, doi:10.1002/hyp.10162, 2015.

Jeelani, G., Shah, R. A., Jacob, N., and Deshpande, R. D.: Estimation of snow and glacier melt contribution to Liddar stream in a mountainous catchment, western Himalaya: an isotopic approach, Isotop. Environ. Health Stud., doi:10.1080/10256016.2016.1186671, in press, 2016.

Jost, G., Moore, R. D., Menounos, B., and Wheate, R.: Quantifying the contribution of glacier runoff to streamflow in the upper Columbia River Basin, Canada, Hydrol. Earth Syst. Sci., 16, 849-860, doi:10.5194/hess-16-849-2012, 2012.

Jouzel, J. and Souchez, R. A.: Melting-refreezing at the glacier sole and the isotopic composition of the ice, J. Glaciol., 28, 35-42, 1982.

Kendall, C. and McDonnell, J. J.: Isotope tracers in catchment hydrology, Elsevier Science Limiter, Amsterdam, 1998.

Klaus, J. and McDonnell, J. J.: Hydrograph separation using stable isotopes: Review and evaluation, J. Hydrol., 505, 47-64, doi:10.1016/j.jhydrol.2013.09.006, 2013.

Kong, Y. and Pang, Z.: Evaluating the sensitivity of glacier rivers to climate change based on hydrograph separation of discharge, J. Hydrol., 434-435, 121-129, doi:10.1016/j.jhydrol.2012.02.029, 2012

Lee, J., Feng, X., Faiia, A. M., Posmentier, E. S., Kirchner, J. W., Osterhuber, R., and Taylor, S.: Isotopic evolution of a seasonal snowcover and its melt by isotopic exchange between liquid water and ice, Chem. Geol., 270, 126-134, doi:10.1016/j.chemgeo.2009.11.011, 2010.

Li, Z., Ross, E., Mosley-Thompson, E., Wang, F., Dong, Z., You, X., Li, H., Li, Z., and Chuanjin, Y.: Seasonal variabilities of ionic concentration in surface snow and elution process in snow-firn packs at PGPI Site on Glacier No. 1 in Eastern Tianshan, China, Ann. Glaciol., 43, 2006.

Magnusson, J., Kobierska, F., Huxol, S., Hayashi, M., Jonas, T., and Kirchner, J. W.: Melt water driven stream and groundwater stage fluctuations on a glacier forefield (Dammagletscher, Switzerland): stream-groundwater interactions on a glacier forefield, Hydrol. Process., 28, 823-836, doi:10.1002/hyp.9633, 2014.

Mair, E., Leitinger, G., Della Chiesa, S., Niedrist, G., Tappeiner, U., and Bertoldi, G.: A simple method to combine snow height and meteorological observations to estimate win- ter precipitation at sub-daily resolution, Hydrolog. Sci. J., doi:10.1080/02626667.2015.1081203, in press, 2016.

Mao, L., Dell'Agnese, A., Huincache, C., Penna, D., Engel, M., Niedrist, G., and Comiti, F.: Bedload hysteresis in a glacier-fed mountain river: bedload hysteresis in a glacierfed mountain river, Earth Surf. Proc. Land., 39, 964-976, doi:10.1002/esp.3563, 2014.

Marshall, S. J.: Meltwater run-off from Haig Glacier, Canadian Rocky Mountains, 2002-2013, Hydrol. Earth Syst. Sci.,18, 5181-5200, doi:10.5194/hess-18-5181-2014, 2014.

Maurya, A. S., Shah, M., Deshpande, R. D., Bhardwaj, R. M., Prasad, A., and Gupta, S. K.: Hydrograph separation and precipitation source identification using stable water isotopes and conductivity: River Ganga at Himalayan foothills, Hydrol. Process., 25, 1521-1530, doi:10.1002/hyp.7912, 2011.

Mukhopadhyay, B. and Khan, A.: A reevaluation of the snowmelt and glacial melt in river flows within Upper Indus Basin and its significance in a changing climate, J. Hydrol., 527, 119-132, doi:10.1016/j.jhydrol.2015.04.045, 2015.

Mutzner, R., Weijs, S. V., Tarolli, P., Calaf, M., Oldroyd, H. J., and Parlange, M. B.: Controls on the diurnal streamflow cycles in two subbasins of an alpine headwater catchment, Water Resour. Res., 51, 3403-3418, doi:10.1002/2014WR016581, 2015.

Ogunkoya, O. O. and Jenkins, A.: Analysis of storm hydrograph and flow pathways using a three-component hydrograph separation model, J. Hydrol., 142, 71-88, 1993.

Ohlanders, N., Rodriguez, M., and McPhee, J.: Stable water isotope variation in a Central Andean watershed dominated by glacier and snowmelt, Hydrol. Earth Syst. Sci., 17, 1035-1050, doi:10.5194/hess-17-1035-2013, 2013.

Penna, D., Stenni, B., Šanda, M., Wrede, S., Bogaard, T. A., Gobbi, A., Borga, M., Fischer, B. M. C., Bonazza, M., and Chárová, Z.: On the reproducibility and repeatability of laser absorption spectroscopy measurements for $\delta^{2} \mathrm{H}$ and $\delta^{18} \mathrm{O}$ isotopic analysis, Hydrol. Earth Syst. Sci., 14, 1551-1566, doi:10.5194/hess-141551-2010, 2010.

Penna, D., Stenni, B., Šanda, M., Wrede, S., Bogaard, T. A., Michelini, M., Fischer, B. M. C., Gobbi, A., Mantese, N., Zuecco, G., Borga, M., Bonazza, M., Sobotková, M., Čejková, B., and Wassenaar, L. I.: Technical Note: Evaluation of between-sample memory effects in the analysis of $\delta^{2} \mathrm{H}$ and $\delta^{18} \mathrm{O}$ of water samples measured by laser spectroscopes, Hydrol. Earth Syst. Sci., 16, 3925-3933, doi:10.5194/hess-16-3925-2012, 2012.

Penna, D., Engel, M., Mao, L., Dell'Agnese, A., Bertoldi, G., and Comiti, F.: Tracer-based analysis of spatial and temporal variations of water sources in a glacierized catchment, Hydrol. Earth Syst. Sci., 18, 5271-5288, doi:10.5194/hess-18-52712014, 2014.

Penna, D., van Meerveld, H. J., Oliviero, O., Zuecco, G., Assendelft, R. S., Dalla Fontana, G., and Borga, M.: Seasonal changes in runoff generation in a small forested mountain catchment, Hydrol. Process., 29, 2027-2042, doi:10.1002/hyp.10347, 2015.

Pinder, G. F. and Jones, J. F., 1969. Determination of ground-water component of peak discharge from chemistry of total runoff, Water Resour. Res., 5, 438-445, doi:10.1029/WR005i002p00438, 1969.

Prasch, M., Mauser, W., and Weber, M.: Quantifying present and future glacier melt-water contribution to runoff in a central $\mathrm{Hi}-$ 
malayan river basin, The Cryosphere 7, 889-904, doi:10.5194/tc7-889-2013, 2013.

Pu, T., He, Y., Zhu, G., Zhang, N., Du, J., and Wang, C.: Characteristics of water stable isotopes and hydrograph separation in Baishui catchment during the wet season in Mt. Yulong region, south western China, Hydrol. Process., 27, 3641-3648, doi:10.1002/hyp.9479, 2013.

Racoviteanu, A. E., Armstrong, R., and Williams, M. W.: Evaluation of an ice ablation model to estimate the contribution of melting glacier ice to annual discharge in the Nepal Himalaya, Water Resour. Res., 49, 5117-5133, doi:10.1002/wrcr.20370, 2013.

Rock, L. and Mayer, B.: Isotope hydrology of the Oldman River basin, southern Alberta, Canada, Hydrol. Process., 21, 33013315, doi:10.1002/hyp.6545, 2007.

Schaefli, B., Hingray, B., and Musy, A.: Climate change and hydropower production in the Swiss Alps: quantification of potential impacts and related modelling uncertainties, Hydrol. Earth Syst. Sci., 11, 1191-1205, doi:10.5194/hess-11-11912007, 2007.

Sklash, M. G.: Environmental isotope studies of storm and snowmelt runoff generation, in: Process studies in hillslope hydrology, edited by: Anderson, M. G. and Burt, T. P., Wiley, Chichester, 401-35, 1990.

Sklash, M. G. and Farvolden, R. N.: Role of groundwater in storm runoff, J. Hydrol., 43, 45-65, doi:10.1016/0022-1694(79)90164$1,1979$.

Stichler, W., Schotterer, U., Fröhlich, K., Ginot, P., Kull, C., Gäggeler, H., and Pouyaud, B.: Influence of sublimation on stable isotope records recovered from high-altitude glaciers in the tropical Andes, J. Geophys. Res., 106, 22613-22620, 2001.

Taylor, S., Feng, X., Kirchner, J. W., Osterhuber, R., Klaue, B., and Renshaw, C. E.: Isotopic evolution of a seasonal snowpack and its melt, Water Resour. Res., 37, 759-769, 2001.
Uhlenbrook, S. and Hoeg, S.: Quantifying uncertainties in tracerbased hydrograph separations: a case study for two-, three- and five-component hydrograph separations in a mountainous catchment, Hydrol. Process., 17, 431-453, doi:10.1002/hyp.1134, 2003.

Vaughn, B. H. and Fountain, A. G.: Stable isotopes and electrical conductivity as keys to understanding water pathways and storage in South Cascade Glacier, Washington, USA, Ann. Glaciol., 40, 107-112, doi:10.3189/172756405781813834, 2005.

Williams, M. W. and Melack, J. M.: Solute chemistry of snowmelt and runoff in an Alpine Basin, Sierra Nevada, Water Resour. Res., 27, 1575-1588, doi:10.1029/90WR02774, 1991.

Wohl, E.: Mountain rivers revisited, vol. 19, American Geophysical Union, 2010

Xing, B., Liu, Z., Liu, G., and Zhang, J.: Determination of runoff components using path analysis and isotopic measurements in a glacier-covered alpine catchment (upper Hailuogou Valley) in southwest China: hydrograph separation; path analysis; glacier-covered catchment, Hydrol. Process., 29, 3065-3073, doi:10.1002/hyp.10418, 2015.

Yde, J. C., Knudsen, N. T., Steffensen, J. P., Carrivick, J. L., Hasholt, B., Ingeman-Nielsen, T., Kronborg, C., Larsen, N. K., Mernild, S. H., Oerter, H., Roberts, D. H., and Russell, A. J.: Stable oxygen isotope variability in two contrasting glacier river catchments in Greenland, Hydrol. Earth Syst. Sci., 20, 1197 1210, doi:10.5194/hess-20-1197-2016, 2016.

Yuanqing, H., Theakstone, W. H., Tandong, Y., and Yafeng, S.: The isotopic record at an alpine glacier and its implications for local climatic changes and isotopic homogenization processes, J. Glaciol., 47, 147-151, doi:10.3189/172756501781832601, 2001.

Zhou, S., Wang, Z., and Joswiak, D. R.: From precipitation to runoff: stable isotopic fractionation effect of glacier melting on a catchment scale, Hydrol. Process., 28, 3341-3349, doi:10.1002/hyp.9911, 2014. 